\title{
Diversification and Community Bank Performance during a Financial Crisis
}

\author{
Kathy Estes ${ }^{\mathrm{i}}$ \\ Bryan, Dayton, TN 37321, United States
}

\begin{abstract}
Many U.S. banks failed or performed poorly during the recent financial crisis. Although the costliest failures were large institutions, the majority of failures were community banks (less than $\$ 1$ billion in total assets). Community banks, which are considered instrumental in small business lending and employment growth, face different risks and challenges than their larger counterparts, including a lack of economies of scale and scope and exclusion from "toobig-to-fail" status. These challenges, coupled with the recent failures, motivate research into potential strategies managers can use to improve performance. This study examined the relationship between three potential diversification strategies and community bank risk-adjusted performance from 2007 to 2011 . Understanding these relationships could improve management's decision-making, allowing them to choose risk-mitigating strategies during a severe economic downturn. Herfindahl-Hirschman Indexes (HHIs) were calculated as proxies for geographic, activity, and asset diversification. Multiple regression models for each of the five years were used to calculate the impact of diversification variables on risk-adjusted ROA. The results show that diversification in all areas is directly related to performance; however, only the asset diversification relationship is significant. To the extent possible for community banks, diversification may improve risk-adjusted performance.
\end{abstract}

Keywords: Diversification; Bank Performance; Finace; Crisis

JEL: G21, G28

(C) 2014 Published by SSBFNET

\section{Introduction}

Since 2007, the United States' financial sector has experienced significant turmoil. The crash of the housing market and the resulting recession characterized by low consumer confidence and high unemployment led to numerous bank and other financial firm failures, financial industry consolidation, and extensive government intervention (Catanach \& Ragatz, 2010). While most of the popular media attention focused on the performance of the largest financial conglomerates and commercial banks and the financial assistance extended to those institutions, community banks were also impacted. Of the 417 banks that failed during 2007 through 2011 , 355, or 85\%, were community banks with less than $\$ 1$ billion in total assets. The dollar amount of these failures ( $\$ 98$ billion) pales in comparison to the

\footnotetext{
${ }^{i}$ Corresponding Author: +1 800-277-9522
} 
\$573 billion of the 62 largest failures, including Washington Mutual (\$307 billion) and IndyMac (\$31 billion), but the impact upon local deposit and loan customers remains substantial (FDIC Failure Data, 2012).

It is tempting to dismiss the importance of community banks to the macro economy given their relative small size. However, a sizable body of literature suggests that community banks play a significant role in small business lending given small business dependence upon financial institutions rather than capital markets and the use of "soft" information needed to make credit decisions regarding these opaque firms. Smaller financial institutions are more likely to obtain this information, build a relationship with the potential customer, and maintain a banking relationship with small businesses (Berger \& Udell, 2002; Scott, 2004; Cole, Goldberg \& White, 2004). Although there have been critics (Davis, Haltiwanger \& Schuh, 1996), conventional wisdom holds that small businesses are responsible for more job creation than larger firms (Birch, 1979), giving them a particularly important role in an economy with high unemployment. Due to the link between community banks and small business lending and employment, community bank health should be a concern for policymakers and other economic participants.

Given the role of community banks within the economy, what are the factors that impact the risk and performance of these institutions? In particular, what community bank management strategies appear to be the most effective during a negative economic shock such as that resulting from the contraction of the housing market during 2007 and forward? This study aimed to further the literature on bank diversification by focusing on a period of industry instability and analyzing the impact of three different diversification strategies (asset, activity, and geographic) on risk-adjusted performance of individual institutions. The impact of three Hirschman-Herfindahl Indexes (HHIs) used as proxies of geographic, asset, and activity diversification on risk-adjusted ROA was assessed using multiple regression analysis of cross-sectional data for the five-year period.

This research differs from previous bank diversification studies by covering a time period largely unstudied in the existing literature and by focusing exclusively on community banks. The five year period exhibited extreme industry volatility and includes a data set after full implementation of the Riele-Neal Act of 1994 and the Gramm Leach Bliley Act of 1999 (GLBA), important milestones for bank diversification practices that are discussed in more detail in the next section. Cotugno and Stefanelli (2012) conducted a study for a similar time period (2005 through 2010) for Italian banks, and Shim (2013) used data through 2011 to analyze the impact of the business cycle and revenue diversification on a bank's capital position; however, neither of these studies examined diversification at U.S. banks. With the exception of Stiroh (2004b), other recent studies have either used the population of all commercial banks/financial firms or have analyzed market value data, which by nature eliminates many community banks from the analysis. Given the research population and time frame under consideration, the results of this study should be meaningful for both community bank managers and regulatory agencies as it gives insight regarding the ability of a community bank to survive or thrive during a negative economic shock. 


\section{Theoretical Foundations}

\subsection{Impact of Regulation and Industry Changes on Performance}

The banking industry has changed significantly in structure and range of services since 1970, driven by a combination of regulatory factors, technological advances, and customers' changing financial demands and payment methods (DeYoung, Hunter \& Udell, 2004). Although the banking industry has always been heavily regulated, the level of regulatory control has cycled. Given the turmoil in the banking industry coinciding with the Great Depression, President Roosevelt signed the Banking Act of 1933, commonly known as the Glass-Steagall Act, into law on June 16, 1933 (FDIC History, 1984). A key provision of this act required the separation of commercial and investment banking activities (Akhigbe \& Whyte, 2001). In addition to activity and asset restrictions, other federal regulations prohibited interstate branching, and many states had restrictive branching laws. Therefore, during the 1960s and 1970s commercial banks were relatively small and offered a traditional slate of services (DeYoung et al., 2004).

Volatile economic conditions and deregulation that started in the 1980s brought change and the potential for additional risk to the banking industry (FDIC History, 1984). During the 1990s globalization and pricing pressures on traditional banking activities reduced profitability for large commercial banks, prompting industry executives to demand regulatory change. Banks also faced increasing competition for funds from the rapidly growing mutual fund industry (Khorana, Servaes \& Tufano, 2005). This combination of factors culminated in the passage of the Financial Services Modernization Act of 1999, more commonly known as the Gramm-Leach-Bliley Act (GLBA) (Czyrnik \& Klein, 2004; Akhigbe \& Whyte, 2001), which allowed financial holding companies to engage in insurance underwriting, securities underwriting and dealing, and merchant banking. As predicted, GLBA spurred consolidation within the industry as well as an expansion of activities conducted by commercial banks and the new financial holding companies (Mamun, Hassaan \& Maroney, 2005), resulting in the percentage of total assets held by the largest financial firms (greater than $\$ 10$ billion in assets) increasing from $62.9 \%$ in 1999 to $79.6 \%$ on December 31,2011 (FDIC Ratios, 2012).

Geographic restrictions on banking were also gradually eliminated during this same time period. The Riegle-Neal Act of 1994 negated the McFadden Act of 1927 ban on interstate branching, and from 1980 through 199432 states loosened their intrastate branch banking restrictions. Deregulation, competition, and industry consolidation forced the total number of banks from 17,886 on March 31, 1984, to 7,357 as of December 31, 2011 (FDIC Annual Income, 2012).

Prior to the industry changes of the last few decades just described, commercial banks generated the bulk of their operating income from net interest income (NII) and non-interest income (NONII) sources comprised only about $20 \%$ of total operating income (DeYoung \& Rice, 2004a). Although NII remains a significant source of operating income, NONII generated from both traditional activities and non-traditional activities has become increasingly important for commercial banks. However, smaller institutions not only have a much lower level of NONII, but the sources of this revenue are more likely to be traditional banking activities such as fees on deposit accounts or cash management. 
Conversely, NONII comprises about $50 \%$ of total operating income for larger institutions and largely stems from mortgage securitization, credit cards, investment banking, and fiduciary accounts (DeYoung \& Rice, 2004a).

Although conventional wisdom has assumed that the growing reliance upon NONII is both necessary and a way to reduce a firm's risk profile, this has not been consistently confirmed by empirical data (DeYoung \& Roland, 1999; Stiroh, 2004a; DeYoung \& Rice, 2004b). Stiroh (2004a) and DeYoung and Rice (2004b) both found that an increased focus on non-interest income is associated with a decline in risk-adjusted performance. NONII may produce higher levels of earnings, but the increased volatility reduces risk-adjusted performance measures. NII and NONII became more highly correlated during the 1990s, indicating that moving into NONII fields may not provide diversification benefits, a relationship noted both within the US and internationally (DeJonghe, 2009; Nguyen, 2012). The overall conclusion of these studies is that NONII may not result in diversification benefits. This study examined this relationship during a crisis period.

\subsection{Financial Crisis}

The immediate cause of the recession was the "bust" in the housing market following an almost steady thirty-year rise in housing prices. Real estate appreciation increased relatively rapidly after the 2000-2001 recession, reaching a peak 2007 before falling steadily through 2011 (FHFA, 2012). Some states, including Nevada, Arizona, Florida, and California, recognized both higher price appreciation and a subsequent higher percentage decline in real estate prices. Macroeconomic conditions caused both asset quality and earnings concerns for the banking industry. Declining collateral values increased the risk of real estate-backed assets, the declining employment picture reduced the repayment capacity of retail loan customers, and declining consumer sentiment and overall business conditions threatened the repayment of commercial loans. At the peak of the crisis approximately 35\% of banks reported negative earnings, and overall 2011 profitability remained below pre-recession levels (FDIC Ratios, 2012). The fact that a majority of institutions continued to report positive earnings indicates that institutions were not equally impacted by the housing market bust and the ensuing recession.

\subsection{Theoretical Foundations of Diversification}

Bank diversification studies comprise a small component of the larger corporate diversification literature. Diamond's (1984) seminal model for financial intermediary diversification concluded commercial banks and insurers could reduce risk through portfolio diversification. As investors in risky assets banks can reduce volatility by using diversification to invest in cash flows imperfectly correlated. Therefore, banks can achieve a more favorable riskreturn frontier, as discussed by Markowitz $(1952 ; 1959)$ in the development of Modern Portfolio Theory (MPT). Early empirical studies from the 1980s and 1990s (i.e. prior to GLBA) used synthetic mergers to study the potential impact on both earnings and risk from the convergence of commercial banking, insurance, securities, and real estate investments (Laderman, 2000; Emmons, Gilbert \& Yeager, 2004). These studies generally concurred with Diamond. In a review of these and other similar studies, Kwan and Laderman (1999) concluded that "Broadening banking firms' revenue base can improve their earnings stability and provide them with a better trade-off between risk and return" (p. 30). 
Three primary types of diversification (geographic, asset, and activity) are assessed in empirical bank diversification studies (Deng, Elyasiani, \& Mao, 2007). Geographic diversification refers to the expanse of geographic area from which a bank's deposits and assets are based; asset diversification denotes the variety found in the institution's balance sheet both among larger asset categories (i.e. cash, securities, and loans) and the breakdown of those individual groups (i.e. loan types); and activity diversification, or revenue diversification, depicts the variety of revenue sources. This latter definition of diversification helps to identify the importance of NII versus NONII or to discern the reliance upon specific NONII sources and involvement in nontraditional banking services such as asset securitization, insurance sales, or securities income.

\subsubsection{Geographic diversification}

The economic performance of the surrounding geographic area affects a bank's financial performance (Aubuchon \& Wheelock, 2010). Factors such as key employers, real estate markets, and financial health of local and state governments can impact the viability of a financial institution and can be good predictors of individual bank performance and credit quality (Zimmerman, 1996; Aubuchon \& Wheelock, 2010; Meyer \& Yeager, 2001). Despite the relaxing of both state and federal branching regulations, many banks still operate within a small geographic area that exposes them to regional economic conditions (Aubuchon \& Wheelock, 2010).

The rationale for geographic diversification is that a bank's performance is not limited to the economy of one particular area. The empirical results for geographic diversification generally show positive performance benefits (Morgan \& Samolyk, 2003; Emmons, Gilbert \& Yeager, 2004; Deng, 2007; Deng \& Elyasiani, 2008; Schmid \& Walter, 2012; Cotugno \& Stefanelli, 2012); however, there are some exceptions. Deng and Elyasiani cautioned that the benefits of geographic diversification may be offset by increasing agency costs at larger distances (Deng \& Elyasiani, 2008; Goetz, Laeven, \& Levine, 2013).

Given the concentration of foreclosure activity within certain states and cities, it is reasonable to assume that the performance of institutions with a wider geographic base may not have experienced the decline faced by others during 2007-2011. However, the degree of geographic diversification by community banks may be insufficient to have a significant impact on performance.

\subsubsection{Asset and activity diversification}

The empirical results for asset and activity diversification are decidedly mixed. In partial support of Diamond's theory, asset diversification has been associated with a lower bond yield-spread, particularly for medium-sized banks; however, activity diversification did not necessarily show the same risk-reduction capability (Deng et al., 2007). Templeton and Severiens (1992) found strong evidence of risk-reduction with an expanded scope of activities, such as security underwriting and insurance, while Lepetit, Patry, and Rous (2004) found a positive value effect for activity and geographic diversification using event study methodology to assess the impact of merger and acquisition activity on the value of target firms in the European banking industry. In addition, value appeared to be created for the acquiring firm when the transactions resulted in more cross-product diversification or less geographic 
diversification. Banks in India were more profitable and had a higher Tobin's Q when their income was derived from multiple sources; however, asset diversity did not appear to impact firm value (Ghosh, 2011). Cotugno and Stefanelli (2012) found improvements in risk-adjusted bank performance from asset diversification at Italian banks, while Shim (2013) considered the impact of the business cycle and NONII on a bank's capital buffer and found evidence that a diversified revenue base is related with a stronger capital buffer.

The above studies noted at least some benefits from either asset or activity diversification, but other studies do not report positive benefits from diversifying characteristics (DeLong, 2001; Acharya, Hasan \& Saunders, 2006; Mercieca, Schaeck \& Wolfe, 2007; Laeven \& Levine, 2007; Schmid \& Walter, 2009). A study of US financial industry mergers showed the market preferred activity-focusing mergers over those resulting in diversification (DeLong, 2001), and management effectiveness can deteriorate if lending expands to new or more competitive industries (Acharya et al., 2006). Several authors noted diversification discounts for U.S. financial conglomerates (Laeven \& Levine; 2007; Schmid \& Walter, 2009), and Stiroh (2004a) found no benefit from activity diversification when using either the level or composition of NONII. The same author (2004b) also studied links between various types of diversification and risk-adjusted performance for all U.S. community banks (less than $\$ 300$ million in total assets) and found diversification benefits within the loan portfolio, but a higher level of NONII was negatively related to risk-adjusted performance. He proposed that diversification benefits may be mitigated by exposure to more volatile revenue streams or from engaging in activities for which they do not have a comparative advantage, a position similarly noted at financial holding companies from 1997 through 2002 (Stiroh \& Rumble, 2006). Fomby, Gunther and $\mathrm{Hu}$ (2012) found an increasing dependence of returns among banks, insurance underwriters, securities brokerage, and mortgage financers during the recent crisis, casting doubt on the risk-adjusted benefits commercial banks can glean from diversifying into these areas.

With the exception of the Fomby et al. (2012) article the studies just referenced use data from approximately the same time period of the mid-1980s through about 2000 to 2004 . Limited research has been conducted for the years subsequent to GLBA's passage in 1999, and only Goetz et al.'s (2013) study of geographic diversification (1986 through 2007) and Shim's (2013) consideration of revenue diversification on capital levels (1992 through 2011) cover the time period used in this study. The years previously studied were generally stable for the commercial banking industry. Therefore, the impact of the housing market bust and the relatively severe economic downturn provide an opportunity to assess the impact of diversification upon bank performance during a widespread and severe economic shock.

\section{Research and Methodology}

\subsection{Data Analysis}

Consistent with prior bank diversification studies (Acharya et al., 2006; Baele et al., 2007; Deng et al., 2007; Deng \& Elyasiani, 2008; Ghosh, 2011; Schmid \& Walter, 2009; Stiroh ,2004a \& b; Stiroh \& Rumble, 2006), the relationships between risk-adjusted performance and bank diversification were assessed using multiple linear regression analysis. 


\subsection{Sample}

The necessary data was obtained from governmental secondary sources. Call Reports filed quarterly by commercial banks with federal regulators and Summary of Deposits (SOD) submitted as of June 30 of each year contained the necessary bank data. MSA unemployment rates obtained from the Bureau of Labor Statistics, a list of publicly-traded banks made available by The Federal Reserve Bank of New York and the Center for Research in Securities Prices (CRSP) and the University of Chicago, and a query report of de novo institutions obtained from the FDIC's Institution Directory provided the remaining data necessary for the research variables.

The definition of a community bank has changed over time as all financial institutions have increased in size. A maximum threshold of $\$ 1$ billion in total assets is a "typical" upper threshold for identifying community banks (DeYoung et al. 2004). A minimum cutoff of $\$ 100$ million in total assets was used given the inability of the smallest institutions to achieve significant diversification (Elyasiani \& Mehdian, 1995; Wheelock \& Wilson, 2001; Yeager, 2004; Berger, Rosen \& Udell, 2007). Financial institutions, including both banks and thrifts, with total assets greater than $\$ 100$ million but less than $\$ 1$ billion included 4,424 institutions and held $10 \%$ of total industry assets as of December 31, 2007 (FDIC Ratios, 2012).

After excluding de novo institutions (established since January 1, 1997), publicly-traded banks, and rural banks (institutions without a branch in an MSA), a sample of 500 banks was selected. Each of these characteristics has been found to systematically alter earnings performance (Stiroh, 2004b; Akhigbe \& McNulty, 2003; Akhigbe \& McNulty, 2005; Nichols, Wahlen and Wieland, 2009). As of December 31, 2007, 2,075 banks remained in the population after the exclusions identified above. The original sample taken from December 31, 2007, was used for all five years of the study. Institutions that failed during the five years were included for the period of their existence, while merged institutions were subsequently included with the acquiring institution and remained in the sample during subsequent years only if the acquiring institution was also part of the sample. Banks whose asset growth or decline resulted in total assets greater than $\$ 1$ billion or less than $\$ 100$ million for 2008 and forward were only included for the years where they met the size parameters.

\section{[Insert Table 1 Here]}

\section{[Insert Table 2 Here]}

\subsection{Hypotheses}

Based on the discussion of previous empirical diversification studies, the null and research hypotheses are listed below. Geographic diversification is predicted to have a positive relationship on risk-adjusted performance, but the impact of activity and asset diversification is not predicted given the mixed results of past studies.

$\mathrm{H}_{0 \mathrm{~A}}$ : Geographic diversification has no relationship to risk-adjusted performance at U.S. community banks between 2007 and 2011. 
$\mathrm{H}_{1 \mathrm{~A}}$ : Geographic diversification is related to improved risk-adjusted performance at U.S. community banks between 2007 and 2011.

$\mathrm{H}_{0 \mathrm{~B}}$ : Activity diversification has no relationship to risk-adjusted performance at U.S. community banks between 2007 and 2011.

$\mathrm{H}_{1 \mathrm{~B}}$ : Activity diversification is related to risk-adjusted performance at U.S. community banks between 2007 and 2011.

$\mathrm{H}_{0 \mathrm{C}}$ : Asset diversification has no relationship to risk-adjusted performance at U.S. community banks between 2007 and 2011.

$\mathrm{H}_{1 \mathrm{C}}$ : Asset diversification is related to risk-adjusted performance at U.S. community banks between 2007 and 2011.

\subsection{Variables}

The regression model contains three groups of variables: independent variables measuring the three types of diversification, a dependent variable representing risk-adjusted performance, and control variables. Each variable, along with its contribution to the research, is discussed below.

Independent variables. The independent variables serve as a proxy for geographic, activity, or asset diversification. The diversification measures are based on an HHI as is common in other bank diversification studies (Acharya et al., 2006; Deng et al., 2007; Ghosh, 2011; Schmid \& Walter, 2009; Stiroh, 2004b) and following the precedence established by Comment and Jarrell (1993) and Lang and Stulz (1994) in broader corporate diversification studies.

Geographic diversification. Community bank diversification is measured with an HHI that considers the distribution of deposits at branches across metropolitan statistical areas (MSAs) defined by the U.S. Census Bureau. This is similar to the geographical measure used by Morgan and Samolyk (2003) to assess geographic diversification among US bank holding companies. Cotugno and Stefanelli (2012) used a similar measure in Italy; however, they used only the number of branches rather than the dollar amount of deposits. The annual SOD data provides the dollar amount of deposits associated with each branch and the branch's MSA location, allowing for an estimate of the proportion of the bank's activity that is conducted in each MSA. In mathematical terms, the indicator is calculated as follows:

$$
H H I_{G s o_{i t}}=\sum_{j=1}^{k}\left(\frac{\text { Depost ts at Bank Erancres In } M S A_{j}}{\text { Total Domestic Bank Deposits }}\right)^{2}
$$

where $\mathrm{i}$ represents the $\mathrm{i}^{\text {th }}$ bank for time period $\mathrm{t}$ (2007 through 2011) and $\mathrm{j}$ represents the MSA where it is located $(\mathrm{j}=1,2,3, \ldots \mathrm{k}$, where $\mathrm{k}$ is equal to $371 \mathrm{MSAs}$ as of December 2006). The value of this indicator using proportions for each MSA ranges from 0 to 1 , where a value of 1 indicates all of a bank's deposits are in the same MSA. Similar to Morgan and Samolyk (2003), deposits at branches not located within an MSA were summed and reported as one area. The index was calculated for each bank for each of the five years. 
Based on previous studies (Cotugno \& Stefanelli, 2012; Deng \& Elyasiani, 2008; Deng, Elyasiani \& Mao, 2007), an increase in geographic diversification, as measured by $\mathrm{HHI}_{\mathrm{Geo}}$ is expected to have a positive impact on risk-based performance. Higher diversification is represented by a lower $\mathrm{HHI}_{\mathrm{Geo}}$, which means the coefficient for this variable is expected to be negative.

Activity diversification. Activity diversification relates to the variety found in a bank's sources of revenue, particularly the level of NONII and the variety of sources for NONII. Similar to Stiroh (2004b), Deng, Elyasiani and Mao (2007), and Schmid and Walter (2009), an HHI of NONII categories was used to capture the level of activity diversification. The HHI for NONII is the sum of squares for each segment as a proportion of total NONII. A high value demonstrates a concentration of fee-generating sources, while institutions with a diverse NONII base would have a relatively low HHI.

The noninterest income categories for which information is available in the Call Reports are included in the equation below. The mathematical calculation for the variable is shown below:

$H H I_{A c t}=\left(\frac{F I D}{N O N}\right)_{i t}^{2}+\left(\frac{S R V}{N O N}\right)_{i t}^{2}+\left(\frac{T R A D}{N O N}\right)_{i t}^{2}+\left(\frac{S \& I}{N O N}\right)_{i t}^{2}+\left(\frac{V E N T}{N O N}\right)_{i t}^{2}+\left(\frac{S E R V}{N O N}\right)_{i t}^{2}+\left(\frac{S E C}{N O N}\right)_{i t}^{2}+\left(\frac{G A I N S}{N O N}\right)_{i t}^{2}+$ $\left(\frac{O T H}{N O N}\right)_{\text {it }}^{2}$

where $\mathrm{i}$ represents the $\mathrm{i}^{\text {th }}$ bank for time period $\mathrm{t}$ (2007 through 2011), NON is the sum of noninterest income, FID is fiduciary income, SRV is service charges on deposit accounts, TRAD is trading revenue, S\&I is the sum of all securities brokerage, investment banking, annuity, and insurance fees and commissions, VENT is venture capital revenue, SERV is net servicing fees, SEC is net securitization income, GAINS is the sum of gains/losses on sales of loans, other real estate, and other assets, and OTH is other noninterest income. The possibility exists that a bank will report negative income for one of the nine noninterest income categories. While the mathematics of the equation (i.e. squaring) would still result in a positive number, a straight summation of the NONII categories may underrepresent the portfolio of noninterest-bearing activities. In order to incorporate the magnitude of all NONII elements, the absolute value of reported income for each NONII category was summed to obtain the denominator (NON). This forces the index values to a domain of zero and one, while continuing to provide a proxy of diversification in NONII activity.

Asset diversification. Asset diversification refers to the dispersion of total assets among large asset groups, such as cash, loans, and investments, and the variety among types of loans and/or securities. Given the role of residential real estate lending in the recent financial crisis, it is beneficial to consider each community bank's loan portfolio mix using an HHI for the loan portfolio. Similar HHIs for asset diversification were utilized by Acharya et al. (2006), Deng et al. (2007), Ghosh (2011), Schmid and Walter (2009), and Stiroh (2004b). If a bank has a loan portfolio wellrepresented across all loan types, the HHI will be relatively low; a bank with a high concentration in one or two types will have a relatively high index. 
The loan types reported in the Call Report are included in the calculation below. In mathematical terms, the index is as shown:

$$
\begin{aligned}
& H_{\text {LOAn it }}=\left(\frac{1-A R E}{\text { LOANS }}\right)_{\text {it }}^{2}+\left(\frac{\text { CONST }}{\text { LOANS }}\right)_{\text {it }}^{2}+\left(\frac{\text { FARM }}{\text { LOANS }}\right)_{\mathrm{it}}^{2}+\left(\frac{\text { MULTI }}{\text { LOANS }}\right)_{\mathrm{it}}^{2}+\left(\frac{C R E}{\text { LOANS }}\right)_{\mathrm{it}}^{2}+\left(\frac{A G}{\text { LOANS }}\right)_{\mathrm{it}}^{2}+\left(\frac{C l}{\text { LOANS }}\right)_{\mathrm{it}}^{2}+ \\
& \left(\frac{\text { CONS }}{\text { LOANS }}\right)_{\mathrm{it}}^{2}+\left(\frac{\text { OTH }}{\text { LOANS }}\right)_{\mathrm{it}}^{2}
\end{aligned}
$$

where $i$ is the $i^{\text {th }}$ bank for time period $t$ (2007 through 2011), LOANS is the sum of all loans, 1-4RE are loans secured by 1-4 family residential properties, CONST is loans secured by real estate and used for construction or other land development, FARM is loans secured by farmland, MULTI is loans secured by multifamily residential properties, $\mathrm{CRE}$ is loans secured by nonfarm nonresidential properties, AG is agricultural loans, $\mathrm{CI}$ is all commercial and industrial loans, CONS is consumer loans, including credit cards, and OTH is the sum of loans to depository institutions, foreign or state and local governments, lease financing, and other loans.

As detailed already, previous empirical studies do not provide a clear picture of the impact of activity or asset diversification on risk-based performance. The inconsistent results make it impossible to predict the coefficient sign for these independent variables. If a low covariance exists between sources noninterest income, indicating benefits from diversification, the resulting sign would be negative. However, previous studies support the possibility of a positive coefficient. Greater loan portfolio diversification which would have limited a bank's exposure to the real estate market downturn may improve risk-adjusted performance and result in a negative coefficient, but previous studies do not uniformly support this position.

Dependent variable. Most community banks are privately held, therefore, an accounting-based dependent variable is more useful than a market-based measure. Risk-adjusted $\mathrm{ROA}\left(\mathrm{RAP}_{\mathrm{ROA}}\right)$ was used as the dependent variable for this study and is calculated as follows:

$R A P_{R O A_{i t}}=\frac{R O A_{i t}}{\sigma_{R O A_{i}}}$

where $\mathrm{i}$ is the $\mathrm{i}^{\text {th }}$ bank for time period $\mathrm{t}$ (2007 through 2011), ROA is the return on assets calculated as net income divided by total assets, and $\sigma_{\mathrm{ROA}}$ is the standard deviation of the ith bank's ROA for the years 2007 through 2011.

Control variables. In order to control for other factors that may impact the risk-adjusted performance of community banks, the following control variables were used.

a. Residential Real Estate Lending $\left(\mathrm{SH}_{\mathrm{RE}}\right)$ : Historically, financial institutions were primarily exposed to real estate lending through direct lending. However, the growth in mortgage-backed securities (MBS) means that banks may be exposed to real estate market weaknesses outside of their normal market area. In order to measure the total exposure to residential real estate, the proportion of residential real estate secured assets to total assets was used as a control variable. Mathematically this variable is shown as:

$S H_{R E_{i t}}=\frac{(1-4 R E+M B S)_{i t}}{\tau A_{\text {it }}}$ 
where $i$ is the $i^{\text {th }}$ bank for time period $t$ (2007 through 2011), MBS is the total of mortgage-backed securities, and TA is total assets. A higher ratio indicates more exposure to the volatile residential real estate market of 2007 through 2011, resulting in a negative coefficient prediction.

b. Asset Size (TA): Larger institutions may be able to benefit from economies of scale and higher risk-adjusted performance (Demsetz \& Strahan, 1997; Wheelock \& Wilson, 2001; Demsetz \& Strahan, 1997; Hunter \& Udell, 2004; Akhigbe \& McNulty, 2005; deHaan \& Poghosyan, 2012). Total assets were used to control for differences in performance related to size. Based on these studies, a positive relationship between asset size and risk-adjusted performance, a positive coefficient for TA, is expected.

c. Multi-Bank Holding Company (MBHC): A dummy variable denoted a bank's membership in a multi-bank holding company. MBHC membership allows affiliated banks to buy and sell loans from one another or for capital transfers from stronger to weaker subsidiaries (Holod \& Peek, 2010). Affiliation could encourage greater risk-taking by management, resulting in lower risk-adjusted performance and a subsidization of weaker subsidiaries (Scharfstein \& Stein, 2000) or could promote greater "efficiency-enhancing specialization among bank subsidiaries" (Holod \& Peek, 2010, p. 879) and cost efficiency (Newman \& Shrieves, 1993). It is estimated that MBHC affiliation (variable equals 1) will have a positive impact on risk-adjusted performance, shown with a positive MBHC variable coefficient.

d. MSA Unemployment Rate (UNEMP): The effects of the recent macroeconomic downturn were not evenly distributed across the U.S. as some regions exhibited higher than average real estate foreclosures and unemployment. Community banks operating in these areas of greater volatility are inherently more likely to have experienced a decline in risk-adjusted performance. In order to consider this disparity, the average annual unemployment rate for the bank's primary MSA is used to proxy for macroeconomic conditions and is expected to be negative.

e. Total Risk-Based Capital Ratio (RBC): Total Risk-Based Capital is calculated as risk-based capital divided by risk-weighted assets and serves as a proxy for management's risk tolerance. Bank managers who are willing to take on more risk are likely to operate the institution with a lower level of capital protection (Acharya et al., 2006; Demsetz \& Strahan, 1997; Stiroh, 2004a; Stiroh, 2004b). It is expected that the level of capital is positively related to risk-adjusted performance resulting in a positive coefficient for this variable.

f. Total Loans to Total Assets (TL/TA): This variable provides information regarding a bank's risk profile and earnings capacity. Loans are usually the most risky commercial bank assets and yield a corresponding risk premium. Therefore, a higher percentage of loans may simultaneously boost earnings, but also increase risk (Stiroh \& Rumble, 2006). Therefore, the sign of the coefficient for the variable, TL/TA, is not predicted.

\section{[Insert Table 3 Here]}

The proposed equation can be summarized as follows: 
$R A P_{R O A}=\alpha+\beta_{1} H H I_{G 80}+\beta_{2} H H I_{A C t}+\beta_{3} H H I_{L O a n}+\beta_{4} S H_{R E}+\beta_{5} T A_{i}+\beta_{6} M B H C_{i}+\beta_{7} U N E M P_{i}+\beta_{8} R B C_{i}+$
$\beta_{9}\left(\frac{\tau L}{\tau A}\right)_{i}+\varepsilon_{i}$

where $i$ is the ith bank in time period $t$ and $\beta_{1}$ through $\beta_{8}$ are the parameters to be estimated. Both the constant $(\alpha)$ and the error term $\left(\varepsilon_{\mathrm{i}}\right)$ are also identified in the model.

\section{Results}

\subsection{Descriptive Statistics}

Data was collected on an original sample of 500 community banks existing as of December 31, 2007. Several of these banks dropped out of the sample by December 31, 2011, due to merger, failure, or falling outside the study size parameters. Other records were missing necessary information. Tables 4 through 8 show the number of banks included in each year's regression model, along with descriptive statistics and skewness and kurtosis statistics for the continuous independent and dependent variables. Table 9 shows the frequency information for the categorical variable HCTMULT (multi-bank holding company).

The range of the dependent variable, $\mathrm{RAP}_{\mathrm{ROA}}$, is greater in 2007 and 2008 as a result of more negative values in those two years. The maximum values cover a relatively narrow range from 32.55 to 34.91 ; the mean covers a range of 2.98 in 2009 to 3.99 in 2007 . This is consistent with generally positive earnings in 2007 compared with weaker earnings in 2009.

The diversification measures show that significant variation in the extent of diversification exists within all three types across the sample. The proxy for asset diversification, $\mathrm{HHI}_{\mathrm{Loan}}$ shows greater diversification with both lower minimums and a lower mean than either $\mathrm{HHI}_{\mathrm{Act}}$ or $\mathrm{HHI}_{\mathrm{Geo}}$. The mean for $\mathrm{HHI}_{\mathrm{Act}}$ demonstrates a consistent trend towards greater diversification over the five-year period, indicating the sample banks further diversified their NONII revenue stream. Geographic diversification appears to be relatively limited, although some banks exhibit strong geographic diversification as shown in the minimums of 0.28 to 0.29 . The much larger $\mathrm{HHI}_{\mathrm{Geo}}$ means show that geographic diversification is limited in this sample of community banks.

Distinct trends in the means of the TA, UNEMP, RBC, and TL/TA variables are also evident. With the exception of 2009, the average size of the community bank sample increased over the five-year period. As expected from known overall macroeconomic conditions, the average MSA unemployment rate for the banks in the sample increased from 2007 through 2010, before falling in 2011. Average RBC decreased slightly in 2008 before steadily increasing through 2011, which may be indicative of lower risk tolerance on the part of bank management resulting from the financial crisis. It is also likely a factor of the falling TL/TA ratios from 2008 to 2011 as the higher risk-weighting for loans would increase the RBC ratio.

Three records were removed from the data given their extreme outlier status. One of the institutions is part of the sample for years 2007 and 2008 before being merged with another institution not found in the sample. Given a very 
small variation in the ROA for those two years, the standard deviation was very small, yielding a high dependent variable and residual standard deviation. One record from 2010 is an institution with extremely negative earnings. This bank drops from the sample during the following year as its size nearly doubles taking it out of the size parameters. These three records were removed from the sample and the descriptive statistics and regression analysis for those three years were redone and are as reported herein.

\author{
[Insert Table 4 Here] \\ [Insert Table 5 Here] \\ [Insert Table 6 Here] \\ [Insert Table 7 Here] \\ [Insert Table 8 Here] \\ [Insert Table 9 Here]
}

\title{
4.2 Normality
}

One of the underlying assumptions of multiple regression is normality of the variables and the error term of the variate. Given the large sample sizes found in each of the five regression models used for this study, the detrimental effects of nonnormality are reduced and may be negligible (Hair, Black, Babin \& Anderson, 2010). Normality was assessed in this study through the use of skewness and kurtosis values for the individual variables and by examining a histogram and P-Plot of the standardized residuals. The skewness and kurtosis values of a normal distribution are zero, with increasing nonnormality depicted as values further from zero. Tables 4 through 8 give the skewness and kurtosis values for each individual variable. The most egregious instances of nonnormality exist for the dependent variable, $\mathrm{RAP}_{\mathrm{ROA}}$, and the $\mathrm{RBC}$ and $\mathrm{HHI}_{\mathrm{Loan}}$ independent variables, all of which show a leptokurtic distribution.

Standardized residual histograms and P-Plots depicted nonnormality in the variate. Given the sample size, the detrimental effects should be negligible on the model. However, in order to obtain normality and assess its impact on the regression models, the $\log$ of the dependent variable, $\mathrm{RAP}_{\mathrm{ROA}}$, was also used. The results of the regression models using the log of $\mathrm{RAP}_{\mathrm{ROA}}$ as the dependent variable found minimal changes to the overall model. In order to use the transformed dependent variable, the records with a negative dependent variable must be dropped from the model. Given the prevalence of negative risk-adjusted performance during a financial crisis, this limits the usefulness of the overall results. Therefore, it was considered more important to retain the negative dependent variable values than to achieve normality, particularly given the sample size of the models. The adjusted regression results are found in the Appendix.

4.3 Regression Results 
A linear regression model was run for each year with $\mathrm{RAP}_{\mathrm{ROA}}$ as the dependent variable and nine independent variables. Eight of the independent variables were continuous, while the dummy variable for being part of a multibank holding company (MBHC) is categorical with the presence of a multi-bank holding company coded as 1 and a one-bank holding company or no holding company coded as 0 . The correlation coefficients for the five models are given in Tables 10 through 14. The results for all five years, including the number of records, r-squared, adjusted rsquared, F-test statistics, and the regression coefficients are found in Table 15.

\section{[Insert Table 10 Here] \\ [Insert Table 11 Here] \\ [Insert Table 12 Here] \\ [Insert Table 13 Here] \\ [Insert Table 14 Here] \\ [Insert Table 15 Here]}

As noted in the table, the r-squared and adjusted r-squared values indicate that a relatively low level of the variation in the dependent variable is explained by the nine independent variables. The 2007 model shows only $4.5 \%$ of the variation in $\mathrm{RAP}_{\mathrm{ROA}}$ is explained, while $10 \%$ of the variation in the 2009 values for $\mathrm{RAP}_{\mathrm{ROA}}$ is explained by the model's independent variables. The remaining models depict adjusted r-squared values between these two limits. The relatively low adjusted r-squared values are not unlike those recognized in previously-published bank diversification studies (Cotugno \& Stefanelli, 2012; Stiroh \& Rumble, 2006; Schmid \& Walter, 2009).

\subsection{Regression Equations}

Using the resulting regression coefficients for each year, the following equations can be used to estimate the riskadjusted return on assets for community banks.
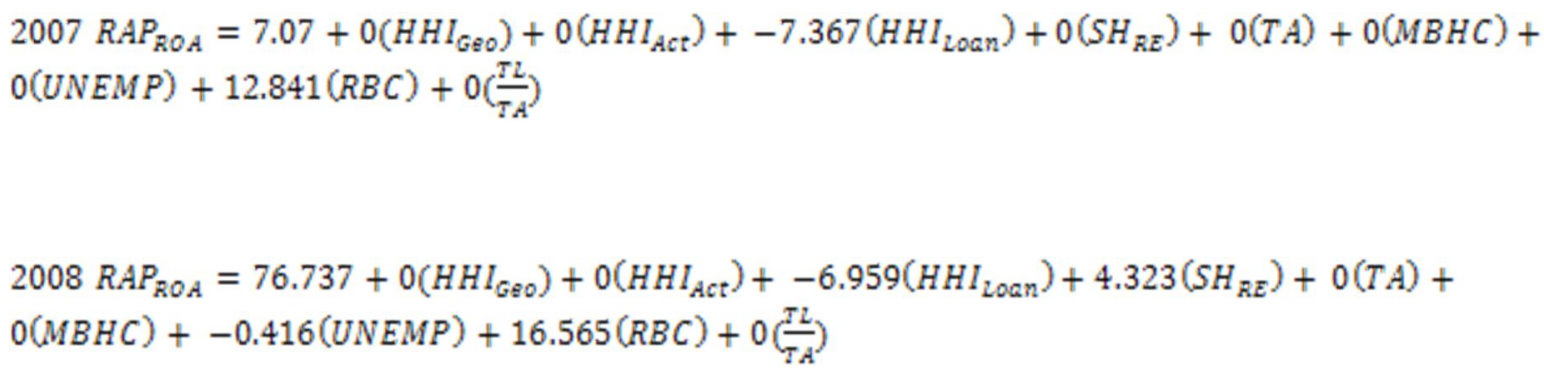
$2009 R A P_{R O A}=6.028+0\left(H H I_{G Q 0}\right)+0\left(H H I_{A C t}\right)+-6.429\left(H H I_{\text {Loan }}\right)+5.468\left(S H_{R E}\right)+0(T A)+$
$1.683(M B H C)+-0.342(U N E M P)+17.871(R B C)+0\left(\frac{\tau L}{T A}\right)$

$$
\begin{aligned}
& 2010 R A P_{R O A}=5.474+0\left(H H I_{G 8 O}\right)+0\left(H H I_{A C t}\right)+-5.994\left(H H I_{\text {Laan }}\right)+3.762\left(S H_{R E}\right)+0(T A)+0(M B H C)+ \\
& -0.367(U N E M P)+19.238(R B C)+0\left(\frac{\tau L}{\tau A}\right)
\end{aligned}
$$

$$
\begin{aligned}
& 2011 R A P_{R O A}=5.110+0\left(H H I_{G 80}\right)+0\left(H H I_{A C t}\right)+-6.624\left(H H I_{\text {Loan }}\right)+0\left(S H_{R E}\right)+0(T A)+1.770(M B H C)+ \\
& -0.408(U N E M P)+17.08(R B C)+0\left(\frac{\tau L}{\tau A}\right)
\end{aligned}
$$

\subsection{Regression Model Analysis}

The independent variables with a significant relationship to $\mathrm{RAP}_{\mathrm{ROA}}$ at the 0.05 significance level in at least one of the five regression models include: $\mathrm{HHI}_{\mathrm{Loan}}, \mathrm{SH}_{\mathrm{RE}}, \mathrm{MBHC}$, UNEMP, and $\mathrm{RBC}$. The $\mathrm{HHI}_{\mathrm{Loan}}$ regression coefficient is consistently negative, indicating that more diversification (lower HHI value) results in higher risk-adjusted performance. The implications of this coefficient are discussed further in the next section under the hypotheses evaluations. The $\mathrm{SH}_{\mathrm{RE}}$ coefficient is positive for all five years, but is only statistically significant for 2008 through 2010. These results are the opposite of the predicted negative coefficient. It was assumed that greater exposure to the real estate market, which was at the center of the recent financial crisis, would result in lower risk-based performance. However, this is not illustrated in the regression results. This may be a reflection of the geographically-centered areas of significant real estate default. In other words, some areas saw a significant increase in real estate defaults; however, others were not as severely impacted. A second explanation is that real estate lending at smaller institutions was generally not as volatile as it was at larger institutions.

The results for all five years show a positive relationship between membership in a multi-bank holding company and risk-adjusted performance; however, the coefficients are significant at the 0.05 level for only 2009 and 2011 and significant at the 0.10 level for 2008 and 2010. This is consistent with the prediction of a positive relationship between $\mathrm{MBHC}$ and risk-adjusted performance and with the expectation of greater efficiency among bank subsidiaries (Holod \& Peek, 2010; Newman \& Shrieves, 1993) and the ability of stronger institutions to lend support to weaker banks (Holod \& Peek, 2010).

As expected, unemployment has an inverse relationship with risk-adjusted performance across the five models, with statistically significant values for 2008 through 2011. The fact that unemployment rates were generally low across the nation in 2007 may be the cause for the lack of a significant relationship in that particular year. Risk-based capital has a statistically significant direct relationship with risk-adjusted performance in all five years. This confirms 
previous results that risk-averse bank managers are more likely to operate with a higher level of capital protection (Acharya et al., 2006; Demsetz \& Strahan, 1997; Stiroh, 2004a; Stiroh, 2004b).

The coefficients for $\mathrm{HHI}_{\mathrm{Geo}}, \mathrm{HHI}_{\mathrm{Act}}$, TA, and TL/TA were not statistically significant in any of the five regression models. Although the coefficients were negative for the geographic and activity diversification proxies, these results should not be relied upon given the lack of statistical significance.

The regression coefficient for TA was negative for years 2007 through 2010 and positive for 2011; the coefficient for TL/TA was negative for 2007 through 2009 and positive for 2010 and 2011. The results for TA are inconsistent with previous studies that have concluded increasing asset size is related to lower risk or improved performance for banks due to greater economies of scale or the use of more leverage (Wheelock \& Wilson, 2001; Demsetz \& Strahan, 1997; Elyasiani \& Mehdian, 1995; Emmons et al., 2004). Given that 2008 and 2009 were the years of the financial crisis exhibiting the lowest industry earnings, the results of this study indicate larger institutions were more vulnerable to the business cycle. This may reflect a higher dependency on non-traditional fee sources which are considered to be more volatile. The most significant loan losses were recognized from the fourth quarter of 2008 through the fourth quarter of 2010. By 2011, charge-offs had declined, allowing for operating efficiencies to once again give large banks higher risk-based performance. The negative coefficient for TL/TA during the peak years of the crisis (2007 through 2009) indicates that the volatility stemming from the riskiness of the loan portfolio outweighed the higher earnings potential associated with a relatively high level of lending. By 2010 and 2011, the higher returns associated with lending overwhelmed the associated volatility.

As discussed in a previous section, the regression models were also run using the log of the dependent variable. The transformed data results show statistically significant coefficients at the 0.05 level in at least one year for $\mathrm{HHI}_{\text {Loan }}(5$ years), $\mathrm{SH}_{\mathrm{RE}}$ (all but 2011), UNEMP (all but 2007), RBC (2007, 2008, \& 2011), and TL/TA (2009). The signs of these coefficients are the same as with the nontransformed data models. The primary difference between the two groups of results is the lack of a statistically significant positive coefficient for MBHC. This may reflect that the strength of affiliated institutions is more critical for banks with a negative risk-based performance, which are not included in the transformed data models.

\subsection{Hypotheses Evaluation}

The regression results for all five years show that greater geographic, activity, and asset diversification are related to improved risk-based performance; however, only the results for asset diversification are statistically significant.

Geographic diversification. The negative regression coefficient for geographic diversification shows an inverse relationship between $\mathrm{HHI}_{\mathrm{Geo}}$ and risk-based performance. A lower $\mathrm{HHI}_{\mathrm{Geo}}$ represents more geographic diversification; therefore, an inverse relationship demonstrates that greater diversification improves risk-based performance. However, the regression coefficients are not statistically significant for any of the five models; therefore, the results cannot be used to reject the null hypothesis. 
Overall, the data shows that community banks are not very well diversified geographically. Approximately one-half of the sample banks only operate within one MSA. The lack of geographic diversification is consistent with Aubuchon and Wheelock's (2010) findings that despite a relaxing of branching regulations, many banks still operate within a small geographic area.

The data also indicates that geographic diversification is directly related to the size of the institution. Table 16 depicts the mean geographic diversification HHI for four size categories and across the five years. The geographic HHIs consistently decrease moving from the smallest banks included in the sample ( $\$ 100$ million- $\$ 250$ million) to the largest ( $\$ 750$ million- $\$ 1$ billion), but the greatest increase in diversification each year comes when considering banks greater than $\$ 750$ million. This is evidence that geographic diversification across MSAs is difficult until banks reach an asset size closer to $\$ 1$ billion.

Based on the results of this study, null hypothesis $\mathrm{H}_{0 \mathrm{~A}}$, which states that geographic diversification has no relationship to risk-adjusted performance at U.S. community banks between 2007 and 2011, is not rejected.

\section{[Insert Table 16 Here]}

Activity diversification. As with geographic diversification, the negative regression coefficients for $\mathrm{HHI}_{\mathrm{Act}}$ show that greater activity diversification is related to improved risk-based performance for all five years. However, the lack of statistical significance once again prevents the related null hypothesis, $\mathrm{H}_{0 \mathrm{~B}}$, from being rejected. The inverse relationship is consistent with the premise that activity diversification allows for greater performance without a mitigating increase in revenue volatility that would reduce risk-adjusted performance.

Similar to geographic diversification, activity diversification appears to increase as community banks increase in size. Table 17 shows the mean activity diversification HHIs for the sample banks in four asset size categories. HHI values consistently fall when moving from the smallest to largest institutions. This indicates that larger size is necessary to achieve greater activity diversification. There also appears to be a trend to greater diversification across the five years, with the greater increases to diversification coming for the smallest institutions.

The existing literature on revenue diversification makes a distinction between traditional and non-traditional sources of fee income, with non-traditional sources shown to be more volatile (DeYoung \& Rice, 2004a \& b). As depicted in Table 18, a relatively low percentage of community bank NONII comes from the more risky and less traditional activities such as trading, venture capital, or securitization of assets. Traditional sources include fiduciary fees (FID), service charges on deposit accounts (SRV), gains on the sales of assets (GAINS), and other noninterest income $(\mathrm{OTH})$. Non-traditional sources include trading revenue (TRAD), income from securities and insurance activities (S\&I), venture capital revenues (VENT), net servicing fees (SERV), and net securitization income (SEC). The data in Table 18 demonstrates that traditional fee sources continue to be the dominant source of noninterest income for community banks and that the largest community banks are more likely to engage in non-traditional revenuegenerating activities. In addition, the very low or negative mean values for non-traditional noninterest income to total noninterest income in 2008 indicate exposure to the business cycle as 2008 is generally considered the high point of 
the financial crisis. This volatility of non-traditional fee sources is consistent with DeYoung and Roland (1999) and DeYoung and Rice (2004). However, non-traditional fee income is such a small factor of community bank income, that the increased volatility of this segment does not outweigh the potential benefits of diversification. Therefore, the coefficient for activity diversification demonstrates that risk-adjusted performance increases with greater activity diversification.

\section{[Insert Table 17 Here] \\ [Insert Table 18 Here]}

Asset diversification. The statistically significant negative regression coefficient for $\mathrm{HHI}_{\mathrm{Loan}}$ in all five models indicates greater asset diversification is related to improved risk-adjusted performance. This lends support for the proposition that a diversified portfolio can reduce risks while maximizing returns, a position consistent with portfolio theory (Markowitz, 1952; 1959) and some previous bank diversification studies (Deng et al., 2007; Stiroh, 2004b; Cotugno \& Stefanelli, 2012). It appears that the movement into a more diversified loan portfolio does not lead to deterioration in management effectiveness. In contrast to geographic and activity diversification, size does not appear to be a factor in the level of loan portfolio diversification. The smallest banks of the sample demonstrate just as much, if not more, diversification than the larger community banks.

Based on the results of this study, null hypothesis $\mathrm{H}_{\mathrm{OC}}$, which states that asset diversification has no relationship to risk-adjusted performance at U.S. community banks between 2007 and 2011, is rejected.

\section{[Insert Table 19 Here]}

Impact of coefficients. The impact on $\mathrm{RAP}_{\mathrm{ROA}}$ of a change in diversification is quantified in Table 20 by demonstrating an increase in diversification from the five-year average maximum HHI value to the five-year average minimum HHI value. The diversification change for each independent variable is given in the Max to Min Avg Diversification column. The change to $\mathrm{RAP}_{\mathrm{ROA}}$ from the increase in diversification is shown in the Impact on $\mathrm{RAP}_{\mathrm{ROA}}$ column, along with the percentage of the impact to the five-year average $\mathrm{RAP}_{\mathrm{ROA}}$ in the last column.

\section{[Insert Table 20 Here]}

\section{Conclusions and Implications}

The linear regression models for each of the five years are statistically significant, but generally explain a relatively low level of the variation in risk-adjusted performance. In summary, the key findings of this study are as follows:

Greater diversification in the loan portfolio among the various types of loan products leads to greater risk-adjusted performance. Bank management can strive to offer a variety of loan products and avoid a portfolio concentrated in only one or two types of loans.

Affiliation with a multi-bank holding company has a positive impact on risk-adjusted performance. 
Banks with higher levels of total risk-based capital, which serves as a proxy for management's risk appetite, also enjoy stronger risk-based earnings.

Unemployment in the local economy has a negative impact on risk-adjusted performance, which shows the vulnerability of financial institutions to overall economic conditions. Management may want to consider stronger geographic diversification to reduce exposure to an economic downturn in one MSA.

A greater share of assets secured by residential real estate in the form of either 1-4 family residential loans or mortgage-backed securities leads to higher risk-adjusted performance. Although this type of lending was the source of significant risk on a national scale during the recent crisis, it does not appear that community banks experienced the same level of volatility.

Community banks struggle to achieve geographic diversification as measured in this study. Therefore, although the results show benefits to risk-based performance from geographically diversifying, the results are statistically insignificant.

Traditional fee services continue to generate most of community bank noninterest revenue. This allows these institutions to largely avoid the volatility generally associated with non-traditional sources. Diversification among noninterest income was found to be beneficial for risk-based performance; however, these results were not statistically significant.

Larger asset size was not beneficial for community banks during the years 2007 through 2010. Although size shows a direct correlation with performance in 2011, the smaller community banks fared better during the previous years. The asset size coefficients are not statistically significant.

Holding a larger percentage of assets in the loan portfolio negatively impacted performance during 2007 through 2009, but was positive for 2010 and 2011. The charge-offs associated with poorly performing loans likely overpowered the higher earnings generally credited to loans during the height of the financial crisis. Once again, the coefficients for this variable are not statistically significant.

A key limitation for this particular study was an appropriate measure for geographic diversification. Although the calculated $\mathrm{HHI}_{\mathrm{Geo}}$ is able to measure diversification across MSAs, the results show that many community banks only operate within one MSA. While that is informative, it does not allow the researcher to distinguish among institutions. This limitation likely reduced the significance of the geographic diversification results.

There are several ways in which this particular study could be expanded to further assess the impact of bank diversification on performance. First of all, the study could be expanded to include the analysis of institutions outside the size parameters used for community banks. Given the systematic differences in bank earnings for different size groups, it would probably be best to analyze the smaller banks and larger banks as separate groups. This would allow the researcher to determine if the results vary based on bank size. However, the smallest institutions would likely 
struggle to gain significant diversification in any of the three areas, therefore, the large bank results may be more informative.

Future studies could also use other measures of performance, including risk-adjusted return on equity or a z-score. A third possibility for publicly-traded firms is Tobin's Q. This would allow for a comparison of results generated from a balance-sheet focused variable versus those stemming from market opinion.

Another area for potential research is to consider other proxies for activity diversification. One possibility would be to explore the relative importance of noninterest income as compared with interest income. This particular study only assessed the importance of variability in noninterest income, but did not assess the impact of overall fee income reliance on risk-adjusted performance. Second, it may be beneficial to consider the impact of traditional commercial bank fee income sources, such as deposit account charges or trust department income, versus nontraditional sources, such as venture capital or securitization fees.

Another suggestion for future research is to compare the results generated from a time of financial crisis to years following the crisis. Given some variation in this study's models across the years, some of which may be explained by the severity of the crisis during that year, it seems reasonable to assume that different results may be gleaned from a period of relative calm in the industry. Structured appropriately, the researcher may also be able to determine if managers have changed strategies with regard to diversification since the crisis.

A final suggestion is to incorporate the use of panel data analysis techniques, such as fixed effects regression models. These statistical techniques would allow the researcher to analyze the change in risk-adjusted performance from a change in the independent variables over time within specific units.

\section{References}

Acharya, V.V., Hasan, I. \& Saunders, A., 2006, Should banks be diversified? Evidence form individual bank loan portfolios. Journal of Business, 79(3), 1355-1412.

Akhigbe, A. \& McNulty, J.E. , 2003, The profit efficiency of small US commercial banks. Journal of Banking \& Finance, 27, 307-325.

Akhigbe, A. \& McNulty, J., 2005, Profit efficiency sources and differences among small and large U.S. commercial banks. Journal of Economics and Finance, 29(3), 289-299.

Akhigbe, A. \& Whyte, A.M., 2001, The market's assessment of the Financial Services Modernization Act of 1999. The Financial Review, 36, 119-138.

Aubuchon, C.P. \& Wheelock, D.C., 2010, The geographic distribution and characteristics of U.S. bank failures, 20072010: Do bank failures still reflect local economic conditions? Federal Reserve Bank of St. Louis Review, 92(5), 395-415.

Baele, L., DeJonghe, O. \& VanderVennet, R., 2007, Does the stock market value bank diversification? Journal of Banking \& Finance, 31(7), 1999-2023.

Berger, A.N., Rosen, R.J. \& Udell, G.F., 2007, Does market size structure affect competition? The case of small business lending. Journal of Banking \& Finance, 31, 11-33. 
Berger, A.N. \& Udell, G.F., 2002, Small business credit availability and relationship lending: The importance of bank organizational structure. The Economic Journal, 112, 32-53.

Birch, D.G.W., 1979, The job generation process. MIT Program on Neighborhood and Regional Change, 302, 1979. Available at SSRN: http://ssrn.com/abstract=1510007.

Catanach, A.H., Jr. \& Ragatz, J.A., 2010, 2008 market crisis: Black swan, perfect storm or tipping point? Bank Accounting \& Finance, 23(3), 20-26.

Cole, R.A., Goldberg, R.A. \& White, L.J., 2004, Cookie cutter vs. character: The micro structure of small business lending by large and small banks. Journal of Financial and Quantitative Analysis, 39(2), 227-251.

Comment, R. \& Jarrell, G.A., 1993, Corporate focus and stock returns. University of Rochester, Bradley Policy Research Center, 1993.

Cotugno, M. \& Stefanelli, V., 2012, Geographical and product diversification during instability financial period: Good or bad for banks? International Research Journal of Finance and Economics, 85, 87-100.

Czyrnik, K. \& Klein, L.S., 2004, Who benefits from deregulating the separation of banking activities? Differential effects on commercial bank, investment bank, and thrift stock returns. The Financial Review, 39 (2), 317 341.

Davis, S.J., Haltiwanger, J.C., \& Schuh, S., 1996, Small business and job creation: Dissecting the myth and reassessing the facts. Small Business Economics, 8(4), 297-315.

deHaan, J. \& Poghosyan, T., 2012, Size and earnings volatility of US bank holding companies. Journal of Banking \& Finance, 36(11), 3008-3016.

DeJonghe, O., 2009, Back to the basics in banking? A micro-analysis of banking system stability. Journal of Financial Intermediation, 19(3), 387-417.

DeLong, G.L., 2001, Stockholder gains from focusing versus diversifying bank mergers. Journal of Financial Economics, 59, 221-252.

Demsetz, R.S. \& Strahan, P.E., 1997, Diversification, size, and risk at bank holding companies. Journal of Money, Credit, and Banking, 29(3), 300-313.

Deng, S., Elyasiani, E. \& Mao, C.X., 2007, Diversification and the cost of debt of bank holding companies. Journal of Banking \& Finance, 31, 2453-2473.

Deng, S. \& Elyasiani, E. , 2008, Geographic diversification, bank holding company value, and risk. Journal of Money, Credit \& Banking, 40(6), 1217-1238.

DeYoung, R., Hunter, W.C. \& Udell, G.E., 2004, The past, present, and probable future for community banks. Journal of Financial Services Research, 25(2/3), 85-133.

DeYoung, R. \& Rice, T., 2004a, How do banks make money? The fallacies of fee income. Economic Perspectives, 28(4), 34-51.

DeYoung, R. \& Rice, T., 2004b, Noninterest income and financial performance at U.S. commercial banks. Financial Review, 39(1), 101-127.

DeYoung, R. \& Roland, K.P., 1999, Product mix and earnings volatility at commercial banks: Evidence from a degree of leverage model. FRB Chicago Working Paper No. 1999-06. Available at SSRN: http://ssrn.com/abstract=251356 or http://dx.doi.org/10.2139/ssrn.251356

Diamond, D.W., 1984, Financial intermediation and delegated monitoring. Review of Economic Studies, 51, 393-414.

Elyasiani, E. \& Mehdian, S., 1995, The comparative efficiency performance of small and large US commercial banks in the pre- and post-deregulation eras. Applied Economics, 27, 1069-1079. 
Emmons, W.R., Gilbert, R.A. \& Yeager, T.J., 2004, Reducing the risk at small community banks: Is it size or geographic diversification that matters? Journal of Financial Services Research, 25(2/3), 259-281.

Federal Deposit Insurance Corporation, 1984, A history of the FDIC 1933-1983. Retrieved from http://www.fdic.gov/bank/analytical/firstfifty/index.html.

Federal Deposit Insurance Corporation, 2012, Annual Income. Retrieved from http://www2.fdic.gov/qbp/.

Federal Deposit Insurance Corporation, 2012, Failures and Assistance Transactions. Retrieved from http://www.fdic.gov/bank/individual/failed/index.html.

Federal Deposit Insurance Corporation, 2012, Ratios by Asset Size Group. Retrieved from http://www2.fdic.gov/qbp/.

Federal Housing Finance Agency, 2012, House Price Index. Retrieved from St. Louis Federal Reserve Economic Data.

Fomby, T.B., Gunther, J.W., \& Hu, J., 2012, Return dependence and the limits of product diversification in financial firms. Journal of Money, Credit and Banking, 44(6), 1151-1183.

Ghosh, S., 2011, Diversification and firm value: Evidence from Indian banks. South Asian Journal of Management, 18(3), 7-25.

Goetz, M.R., Laeven, L. \& Levine, R., 2013, Identifying the valuation effects and agency costs of corporate diversification: Evidence from the geographic diversification of U.S. banks. Review of Financial Studies, 26(7), 1787-1823.

Hair, J.F., Jr., Black, W.C., Babin, B.J. \& Anderson, R.E., 2010, Multivariate data analysis ( $7^{\text {th }}$ ed.). Upper Saddle River, NJ: Prentice Hall.

Holod, D. \& Peek, J., 2010, Capital constraints, asymmetric information, and internal capital markets in banking: New evidence. Journal of Money, Credit and Banking, 42(5), 879-906.

Khorana, A., Servaes, H. \& Tufano, P., 2005, Explaining the size of the mutual fund industry around the world. Journal of Financial Economics, 78(1), 145-185.

Kwan, S.H. \& Laderman, E.S., 1999, On the portfolio effects of financial convergence - A review of the literature. FRBSF Economic Review, 2, 18-31.

Laderman, E.S., 2000, The potential diversification and failure reduction benefits of bank expansion into nonbank activities. Federal Reserve Bank of San Francisco Working Paper, 2000-01.

Laeven, L. \& Levine, R., 2007, Is there a diversification discount in financial conglomerates? Journal of Financial Economics, 85, 331-367.

Lang, L.H.P. \& Stulz, R.M., 1994, Tobin's q, corporate diversification, and firm performance. Journal of Political Economy, 102, 1248-1280.

Lepetit, L., Patry, S. \& Rous, P., 2004, Diversification versus specialization: an event study of M\&As in the European banking industry. Applied Financial Economics, 14, 663-669.

Mamun, A., Hassan, M.K. \& Maroney, N., 2005, The wealth and risk effects of the Gramm-Leach-Bliley Act (GLBA) on the US banking industry. Journal of Business, Finance \& Accounting, 32(1\&2), 351-388.

Markowitz, H. M., 1952, Portfolio selection. Journal of Finance, 77- 91.

Markowitz, H.M., 1959, Portfolio selection: Efficient diversification of investments. New York: John Wiley \& Sons.

Mercieca, S., Schaeck, K. \& Wolfe, S., 2007, Small European banks: Benefits from diversification? Journal of Banking \& Finance, 31, 1975-1998. 
Meyer, A.P. \& Yeager, T.J., 2001, Are small rural banks vulnerable to local economic downturns? Federal Reserve Bank of St. Louis Review, 83(2), 25-38.

Morgan, D.P. \& Samolyk, K., 2003, Geographic diversification in banking and its implications for bank portfolio choice and performance. Working Paper, Federal Reserve Bank of New York, February 20, 2003, 1-30.

Newman, J.A. \& Shrieves, R.E., 1993, The multibank holding company effect on cost efficiency in banking. Journal of Banking \& Finance, 17(4), 709-732.

Nguyen, J., 2012, The relationship between net interest margin and noninterest income using a system estimation approach. Journal of Banking \& Finance, 36, 2429-2437.

Nichols, D.C., Wahlen, J.M., Wieland, M.M., 2009, Publicly-traded versus privately held: Implications for conditional conservatism in bank accounting. Review of Accounting Studies, 14(1), 88-122.

Scharfstein, D.S. \& Stein, J.C., 2000, The dark side of internal capital markets: Divisional rent-seeking and inefficient investment. Journal of Finance, 55(6), 2537-2564.

Schmid, M.M. \& Walter, I., 2009, Do financial conglomerates create or destroy economic value? Journal of Financial Intermediation, 18, 193-216.

Schmid, M.M. \& Walter, I., 2012, Geographic diversification and firm value in the financial services industry. Journal of Empirical Finance, 19(1). 109-122.

Scott, J.A., 2004, Small business and the value of community financial institutions. Journal of Financial Services Research, 25(2/3), 207-230.

Shim, J., 2013, Bank capital buffer and portfolio risk: The influence of business cycle and revenue diversification. Journal of Banking \& Finance, 37, 761-772.

Stiroh, K.J., 2004a, Diversification in banking: Is noninterest income the answer? Money Credit and Banking, 36(5), 853-882.

Stiroh, K.J., 2004b, Do community banks benefit from diversification? Journal of Financial Services Research, 25(2/3), 135-160.

Stiroh, K.J. \& Rumble, A., 2006, The dark side of diversification: The case of US financial holding companies. Journal of Banking \& Finance, 30, 2131-2161.

Templeton, W.K. \& Severiens, J.T., 1992, The effect of nonbank diversification on bank holding companies. Quarterly Journal of Business and Economics, 31(4), 3-16.

Wheelock, D.C. \& Wilson, P.W., 2001, New evidence on returns to scale and product mix among U.S. commercial banks. Journal of Monetary Economics, 47, 653-674.

Yeager, T.J., 2004, The demise of community banks? Local economic shocks are not to blame. Journal of Banking \& Finance, 28, 2135-2153.

Zimmerman, G.C., 1996, Factors influencing community bank performance in California. FRBSF Economic Review, $1,26-42$.

[Insert Appendix Table Here] 
Table 1: Data from Reports of Condition and Income (Call Reports)

\begin{tabular}{|c|c|c|c|c|c|c|c|}
\hline Data & Identifier & $\begin{array}{c}\text { Call } \\
\text { Report } \\
\text { Schedule } \\
\end{array}$ & \multicolumn{5}{|c|}{ Call Report Line Number } \\
\hline & & & & 2008 & 2009 & 2010 & 2011 \\
\hline Income from fiduciary activities & FID & $\begin{array}{l}\text { RI - } \\
\text { Income }\end{array}$ & $\begin{array}{c}\mathbf{2 0 0 7} \\
\text { RIAD4070 }\end{array}$ & RIAD4070 & RIAD4070 & RIAD4070 & RIAD4070 \\
\hline Service charges on deposit accounts & SRV & $\begin{array}{l}\text { Statement } \\
\text { RI - } \\
\text { Income }\end{array}$ & RIAD4080 & RIAD4080 & RIAD4080 & RIAD4080 & RIAD4080 \\
\hline Trading Revenue & TRAD & $\begin{array}{c}\text { Statement } \\
\text { RI - } \\
\text { Income } \\
\text { Statement }\end{array}$ & RIADA220 & RIADA220 & RIADA220 & RIADA220 & RIADA220 \\
\hline $\begin{array}{l}\text { Fees and commissions from securities brokerage, investment banking, } \\
\text { annuity sales, and insurance }\end{array}$ & S\&I & $\begin{array}{l}\text { RI - } \\
\text { Income } \\
\text { Statement }\end{array}$ & $\begin{array}{c}\text { RIADC } 886, \\
888,887, \\
386,387\end{array}$ & $\begin{array}{c}\text { RIADC886, } \\
888,887,386, \\
387\end{array}$ & $\begin{array}{l}\text { RIADC } 886, \\
888,887,386, \\
387\end{array}$ & $\begin{array}{c}\text { RIADC } 886, \\
888,887,386 \\
387\end{array}$ & $\begin{array}{l}\text { RIADC } 886, \\
888,887,386, \\
387\end{array}$ \\
\hline Venture capital revenue & VENT & $\begin{array}{l}\text { RI - } \\
\text { Income }\end{array}$ & RIADB491 & RIADB491 & RIADB491 & RIADB491 & RIADB491 \\
\hline Net servicing fees & SERV & $\begin{array}{l}\text { Statement } \\
\text { RI - } \\
\text { Income }\end{array}$ & RIADB492 & RIADB492 & RIADB492 & RIADB492 & RIADB492 \\
\hline Gains on sales of loans, leases, other real estate, and other assets & GAINS & $\begin{array}{c}\text { Statement } \\
\text { RI - } \\
\text { Income } \\
\text { Statement }\end{array}$ & $\begin{array}{l}\text { RIAD5416, } \\
5415, \\
\text { RIADB496 }\end{array}$ & $\begin{array}{l}\text { RIAD } 5416, \\
5415, \\
\text { RIADB496 }\end{array}$ & $\begin{array}{l}\text { RIAD5416, } \\
5415, \\
\text { RIADB496 }\end{array}$ & $\begin{array}{l}\text { RIAD5416, } \\
5415, \\
\text { RIADB496 }\end{array}$ & $\begin{array}{l}\text { RIAD5416, } \\
5415, \\
\text { RIADB496 }\end{array}$ \\
\hline Other noninterest income & OTH & $\begin{array}{c}\text { RI - } \\
\text { Income } \\
\text { Statement }\end{array}$ & RIADB497 & RIADB497 & RIADB497 & RIADB497 & RIADB497 \\
\hline Total noninterest income & NON & $\begin{array}{c}\text { RI - } \\
\text { Income } \\
\text { Statement }\end{array}$ & RIAD4079 & RIAD4079 & RIAD4079 & RIAD4079 & RIAD4079 \\
\hline $1-4$ family residential loans & $1-4 \mathrm{RE}$ & $\begin{array}{l}\text { RC-C } \\
\text { Loans and } \\
\text { Leases }\end{array}$ & $\begin{array}{c}\text { RCON1797, } \\
5367,5368\end{array}$ & $\begin{array}{l}\text { RCON1797, } \\
5367,5368\end{array}$ & $\begin{array}{l}\text { RCON1797, } \\
5367,5368\end{array}$ & $\begin{array}{l}\text { RCON1797, } \\
5367,5368\end{array}$ & $\begin{array}{l}\text { RCON1797, } \\
5367,5368\end{array}$ \\
\hline Construction, land development, and other land loans & CONST & $\begin{array}{l}\text { RC-C } \\
\text { Loans and } \\
\text { Leases }\end{array}$ & RCON1415 & $\begin{array}{l}\text { RCONF158, } \\
159\end{array}$ & $\begin{array}{l}\text { RCONF158, } \\
\quad 160\end{array}$ & $\begin{array}{l}\text { RCONF158, } \\
\quad 161\end{array}$ & $\begin{array}{l}\text { RCONF158, } \\
\quad 162\end{array}$ \\
\hline
\end{tabular}


Estes /International Journal of Finance \& Banking Studies Vol 3, No 4, 2014 ISSN: 2147-4486

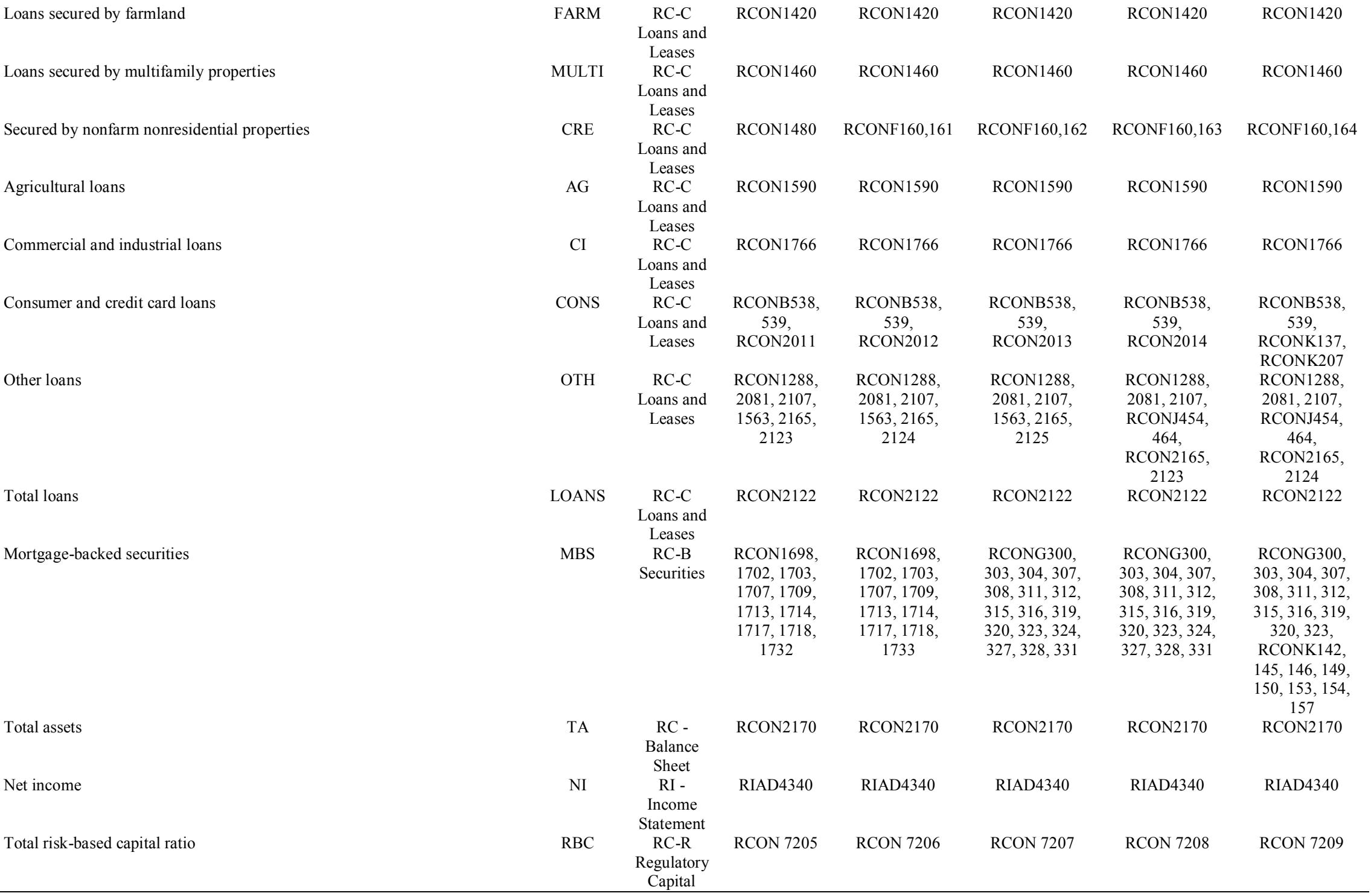


Table 2. Summary of Deposits Data

\begin{tabular}{|c|c|}
\hline Field & Definition \\
\hline ADDRESBR & Address (Branch) \\
\hline ADDRESS & Address (Institution) \\
\hline CERT & FDIC Certificate Number \\
\hline CNTYNAMB & County Name (Branch) \\
\hline DEPDOM & Deposits, Total Domestic - Institution \\
\hline DEPSUMBR & Deposits (Branch)(in thousands of dollars) \\
\hline HCTMULT & Multi-Bank Holding Company flag \\
\hline MSABR & Metropolitan Statistical areas \\
\hline MSANAMB & Metropolitan Statistical area Name \\
\hline TOTBR & Total Branches \\
\hline TOTDEP & Total Deposits - Institution \\
\hline
\end{tabular}


Table 3. Variable Definitions

\begin{tabular}{|c|c|}
\hline Variable & Definition \\
\hline \multicolumn{2}{|l|}{ Dependent Variable: } \\
\hline $\mathrm{RAP}_{\mathrm{ROA}}$ & Annual ROA divided by the 2007-2011 standard deviation of ROA \\
\hline \multicolumn{2}{|l|}{ Diversification Measures: } \\
\hline $\mathrm{HHI}_{\mathrm{Geo}}$ & HHI of bank deposits across MSAs \\
\hline $\mathrm{HHI}_{\text {Act }}$ & HHI of a bank's noninterest income sources \\
\hline $\mathrm{HHI}_{\text {Loan }}$ & HHI of a bank's loan portfolio mix \\
\hline \multirow{2}{*}{\multicolumn{2}{|c|}{$\begin{array}{l}\text { Control Variables: } \\
\qquad \mathrm{SH}_{\mathrm{RE}}\end{array}$}} \\
\hline & \\
\hline & Percentage of bank assets comprised of 1-4 family residential real estate loans or mortgage-backed securities \\
\hline TA & Bank asset size in dollars \\
\hline \multicolumn{2}{|l|}{ MBHC } \\
\hline & Equals 1 if the bank is part of a multi-bank holding company; Equals 0 if not \\
\hline UNEMP & Annual MSA unemployment rate \\
\hline $\mathrm{RBC}$ & Total Risk-Based Capital to Risk-Weighted Assets \\
\hline TL/TA & Percentage of bank's assets held in the loan portfolio \\
\hline
\end{tabular}


Table 4. 2007 Descriptive Statistics

\begin{tabular}{lcccccccccc}
\hline Variable & $\mathrm{N}$ & Min & Max & Range & Mean & St. Dev. & Skewness & $\begin{array}{c}\text { Std. } \\
\text { Error }\end{array}$ & Kurtosis & $\begin{array}{c}\text { Std. } \\
\text { Error }\end{array}$ \\
\hline RAPROA & 490 & -10.6801 & 32.8963 & 43.5764 & 3.9858 & 4.7324 & 2.7340 & 0.1100 & 11.1710 & 0.2200 \\
HHIGeo & 490 & 0.2902 & 1.0000 & 0.7551 & 0.8455 & 0.1997 & -0.9330 & 0.1100 & -0.5730 & 0.2200 \\
HHIAct & 490 & 0.2165 & 0.9573 & 0.7408 & 0.4608 & 0.1384 & 0.7660 & 0.1100 & 0.5310 & 0.2200 \\
HHILoan & 490 & 0.1490 & 0.9653 & 0.8163 & 0.3021 & 0.1337 & 2.1930 & 0.1100 & 5.8290 & 0.2200 \\
SHRE & 490 & 0.0093 & 0.9067 & 0.8974 & 0.2659 & 0.1576 & 1.0750 & 0.1100 & 1.1270 & 0.2200 \\
TA & 490 & $100,272.00$ & $988,365.00$ & $888,093.00$ & $319,845.70$ & $207,015.52$ & 1.3440 & 0.1100 & 1.0840 & 0.2200 \\
Unemp & 490 & 2.0750 & 8.5333 & 6.4583 & 4.3508 & 0.8835 & 0.6330 & 0.1100 & 2.0870 & 0.2200 \\
RBCapital & 490 & 0.0480 & 0.4911 & 0.4431 & 0.1499 & 0.0563 & 2.4460 & 0.1100 & 7.9680 & 0.2200 \\
L/A & 490 & 0.0895 & 0.9559 & 0.8664 & 0.6940 & 0.1322 & -0.9900 & 0.1100 & 1.4030 & 0.2200 \\
\hline
\end{tabular}

Table 5. 2008 Descriptive Statistics

\begin{tabular}{lcccccccccc}
\hline Variable & $\mathrm{N}$ & Min & Max & Range & Mean & St. Dev. & Skewness & $\begin{array}{c}\text { Std. } \\
\text { Error }\end{array}$ & Kurtosis & $\begin{array}{c}\text { Std. } \\
\text { Error }\end{array}$ \\
\hline RAPROA & 484 & -12.0943 & 34.9127 & 47.0070 & 3.2723 & 4.8855 & 2.6320 & 0.1110 & 10.6410 & 0.2220 \\
HHIGeo & 484 & 0.2838 & 1.0000 & 0.7833 & 0.8406 & 0.2014 & -0.8950 & 0.1110 & -0.6060 & 0.2220 \\
HHIAct & 484 & 0.2095 & 0.9676 & 0.7581 & 0.4490 & 0.1388 & 0.9830 & 0.1110 & 1.2010 & 0.2220 \\
HHILoan & 484 & 0.1491 & 0.9728 & 0.8237 & 0.2993 & 0.1304 & 2.2090 & 0.1110 & 6.0550 & 0.2220 \\
SHRE & 484 & 0.0079 & 0.8958 & 0.8879 & 0.2851 & 0.1596 & 0.9730 & 0.1110 & 0.8860 & 0.2220 \\
TA & 484 & $94,447.00$ & $998,546.00$ & $904,099.00$ & $335,418.17$ & $214,667.27$ & 1.3070 & 0.1110 & 0.9920 & 0.2220 \\
Unemp & 484 & 2.7500 & 10.5000 & 7.7500 & 5.2681 & 1.1391 & 0.5760 & 0.1110 & 1.6550 & 0.2220 \\
RBCapital & 484 & 0.0530 & 0.5046 & 0.4516 & 0.1467 & 0.0555 & 2.6070 & 0.1110 & 9.8500 & 0.2220 \\
L/A & 484 & 0.0816 & 0.9579 & 0.8763 & 0.7006 & 0.1356 & -1.0300 & 0.1110 & 1.4300 & 0.2220 \\
\hline
\end{tabular}


Table 6. 2009 Descriptive Statistics

\begin{tabular}{lcccccccccc}
\hline Variable & $\mathrm{N}$ & Min & Max & Range & Mean & St. Dev. & Skewness & $\begin{array}{c}\text { Std. } \\
\text { Error }\end{array}$ & Kurtosis & $\begin{array}{c}\text { Std. } \\
\text { Error }\end{array}$ \\
\hline RAPROA & 461 & -3.0791 & 32.5516 & 35.6303 & 2.9838 & 4.9741 & 2.6290 & 0.1140 & 9.8300 & 0.2270 \\
HHIGeo & 461 & 0.2864 & 1.0000 & 0.7578 & 0.8360 & 0.2018 & -0.8560 & 0.1140 & -0.6370 & 0.2270 \\
HHIAct & 461 & 0.1921 & 0.9458 & 0.7537 & 0.4337 & 0.1377 & 1.0440 & 0.1140 & 1.5000 & 0.2270 \\
HHILoan & 461 & 0.1458 & 0.9704 & 0.8247 & 0.3027 & 0.1280 & 2.1810 & 0.1140 & 6.1410 & 0.2270 \\
SHRE & 461 & 0.0073 & 0.8323 & 0.8250 & 0.2804 & 0.1523 & 0.9100 & 0.1140 & 0.7150 & 0.2270 \\
TA & 461 & $105,247.00$ & $1,040,094.00$ & $934,847.00$ & $347,578.03$ & $213,520.68$ & 1.2640 & 0.1140 & 0.9100 & 0.2270 \\
Unemp & 461 & 3.7333 & 15.2250 & 11.4917 & 8.3715 & 1.8291 & 0.2760 & 0.1140 & 0.7290 & 0.2270 \\
RBCapital & 461 & 0.0280 & 0.5278 & 0.4998 & 0.1495 & 0.0565 & 2.5630 & 0.1140 & 10.4380 & 0.2270 \\
L/A & 461 & 0.0779 & 0.9416 & 0.8637 & 0.6751 & 0.1321 & -0.8540 & 0.1140 & 1.1000 & 0.2270 \\
\hline
\end{tabular}

Table 7. 2010 Descriptive Statistics

\begin{tabular}{lcccccccccc}
\hline Variable & $\mathrm{N}$ & Min & Max & Range & Mean & St. Dev. & Skewness & $\begin{array}{c}\text { Std. } \\
\text { Error }\end{array}$ & Kurtosis & Error \\
\hline RAPROA & 437 & -2.4734 & 32.4785 & 34.9518 & 3.4406 & 5.1072 & 2.5470 & 0.1170 & 9.1520 & 0.2330 \\
HHIGeo & 437 & 0.2899 & 1.0000 & 0.7489 & 0.8280 & 0.2039 & -0.7550 & 0.1170 & -0.8440 & 0.2330 \\
HHIAct & 437 & 0.2000 & 0.9221 & 0.7221 & 0.4200 & 0.1394 & 1.2660 & 0.1170 & 1.9590 & 0.2330 \\
HHILoan & 437 & 0.1348 & 0.9598 & 0.8250 & 0.3070 & 0.1252 & 1.9960 & 0.1170 & 5.2580 & 0.2330 \\
SHRE & 437 & 0.0038 & 0.7814 & 0.7776 & 0.2818 & 0.1451 & 0.7770 & 0.1170 & 0.6430 & 0.2330 \\
TA & 437 & $97,831.00$ & $995,403.00$ & $897,572.00$ & $342,747.58$ & $210,480.48$ & 1.3120 & 0.1170 & 1.0590 & 0.2330 \\
Unemp & 437 & 3.7667 & 17.2500 & 13.4833 & 8.5770 & 1.8532 & 0.3940 & 0.1170 & 1.8090 & 0.2330 \\
RBCapital & 437 & 0.0349 & 0.5572 & 0.5223 & 0.1579 & 0.0602 & 2.4810 & 0.1170 & 10.1790 & 0.2330 \\
L/A & 437 & 0.0761 & 0.9327 & 0.8565 & 0.6591 & 0.1285 & -0.8040 & 0.1170 & 1.0660 & 0.2330 \\
\hline
\end{tabular}


Table 8. 2011 Descriptive Statistics

\begin{tabular}{lcccccccccc}
\hline Variable & $\mathrm{N}$ & Min & Max & Range & Mean & St. Dev. & Skewness & $\begin{array}{c}\text { Std. } \\
\text { Error }\end{array}$ & Kurtosis & Error \\
\hline RAPROA & 423 & -2.6331 & 33.4146 & 36.0477 & 3.6326 & 5.0684 & 2.5200 & 0.1190 & 8.9300 & 0.2370 \\
HHIGeo & 423 & 0.2775 & 1.0000 & 0.7596 & 0.8299 & 0.2008 & -0.7550 & 0.1190 & -0.8200 & 0.2370 \\
HHIAct & 423 & 0.2084 & 0.9956 & 0.7871 & 0.4091 & 0.1306 & 1.3510 & 0.1190 & 2.6830 & 0.2370 \\
HHILoan & 423 & 0.1456 & 0.9904 & 0.8449 & 0.3120 & 0.1255 & 1.9700 & 0.1190 & 5.4260 & 0.2370 \\
SHRE & 423 & 0.0180 & 0.8226 & 0.8046 & 0.2898 & 0.1484 & 0.7710 & 0.1190 & 0.5510 & 0.2370 \\
TA & 423 & $95,433.00$ & $986,320.00$ & $890,887.00$ & $346,408.52$ & $210,648.41$ & 1.2700 & 0.1190 & 0.8930 & 0.2370 \\
Unemp & 423 & 3.3750 & 16.8750 & 13.5000 & 7.9721 & 1.7978 & 0.5670 & 0.1190 & 2.3900 & 0.2370 \\
RBCapital & 423 & 0.0089 & 0.5723 & 0.5634 & 0.1678 & 0.0648 & 2.2460 & 0.1190 & 9.3340 & 0.2370 \\
L/A & 423 & 0.0772 & 0.9320 & 0.8547 & 0.6335 & 0.1319 & -0.7290 & 0.1190 & 0.8430 & 0.2370 \\
\hline
\end{tabular}

Table 9. MBHC Frequencies.

1=Multi-bank holding company;

$0=$ One-bank holding company or no holding company

\begin{tabular}{lccccc}
\hline & 2007 & 2008 & 2009 & 2010 \\
\hline 0 & 426 & 418 & 401 & 385 \\
1 & 64 & 66 & 60 & 373 \\
Total & 490 & 484 & 461 & 50 & 437 \\
\hline
\end{tabular}


Table 10. 2007 Correlation Matrix

\begin{tabular}{|c|c|c|c|c|c|c|c|c|c|c|}
\hline Variable & RAPROA & $\mathrm{HHI}_{\mathrm{Geo}}$ & $\mathrm{HHI}_{\text {Act }}$ & $\mathrm{HHI}_{\text {Loan }}$ & $\mathrm{SH}_{\mathrm{RE}}$ & TA & HCTMULT & Unemp Rate & $\mathrm{RBC}$ & TL/TA \\
\hline RAPROA & 1 & & & & & & & & & \\
\hline $\mathrm{HHI}_{\mathrm{Geo}}$ & $\begin{array}{l}-0.039 \\
(0.391\end{array}$ & 1 & & & & & & & & \\
\hline $\mathrm{HHI}_{\mathrm{Act}}$ & $\begin{array}{l}-0.049 \\
(0.281)\end{array}$ & $\begin{array}{l}0.081 * \\
(0.071)\end{array}$ & 1 & & & & & & & \\
\hline $\mathrm{HHI}_{\text {Loan }}$ & $\begin{array}{c}-0.129 * * * \\
(0.004)\end{array}$ & $\begin{array}{c}0.193 * * * \\
(0.000)\end{array}$ & $\begin{array}{c}0.160 * * * \\
(0.000)\end{array}$ & 1 & & & & & & \\
\hline $\mathrm{SH}_{\mathrm{RE}}$ & $\begin{array}{c}0.021 \\
(0.648)\end{array}$ & $\begin{array}{c}0.183^{* * *} \\
(0.000)\end{array}$ & $\begin{array}{l}-0.073 \\
(0.102)\end{array}$ & $\begin{array}{c}0.523 * * * \\
(0.000)\end{array}$ & 1 & & & & & \\
\hline TA & $\begin{array}{c}-0.066 \\
(0.146)\end{array}$ & $\begin{array}{c}-0.212^{* * *} \\
(0.000)\end{array}$ & $\begin{array}{c}-0.266^{* * *} \\
(0.000)\end{array}$ & $\begin{array}{c}0.059 \\
(0.190)\end{array}$ & $\begin{array}{c}0.046 \\
(0.301)\end{array}$ & 1 & & & & \\
\hline HCTMULT & $\begin{array}{c}0.068 \\
(0.133)\end{array}$ & $\begin{array}{l}-0.071 \\
(0.113)\end{array}$ & $\begin{array}{c}0.014 \\
(0.758)\end{array}$ & $\begin{array}{c}-0.122 * * * \\
(0.006)\end{array}$ & $\begin{array}{c}-0.101^{* *} \\
(0.025)\end{array}$ & $\begin{array}{c}0.011 \\
(0.809)\end{array}$ & 1 & & & \\
\hline Unemp Rate & $\begin{array}{l}-0.007 \\
(0.875)\end{array}$ & $\begin{array}{c}0.120 * * * \\
(0.008)\end{array}$ & $\begin{array}{c}0.002 \\
(0.969)\end{array}$ & $\begin{array}{c}0.134 * * * \\
(0.003)\end{array}$ & $\begin{array}{c}0.168 * * * \\
(0.000)\end{array}$ & $\begin{array}{c}0.003 \\
(0.943)\end{array}$ & $\begin{array}{c}0.041 \\
(0.366)\end{array}$ & 1 & & \\
\hline $\mathrm{RBC}$ & $\begin{array}{c}0.105^{* *} \\
(0.02)\end{array}$ & $\begin{array}{c}0.206^{* * * *} \\
(0.000)\end{array}$ & $\begin{array}{c}0.17 * * * \\
(0.000)\end{array}$ & $\begin{array}{c}0.37 * * * \\
(0.000)\end{array}$ & $\begin{array}{c}0.287 * * * \\
(0.000)\end{array}$ & $\begin{array}{c}-0.139 * * * \\
(0.002)\end{array}$ & $\begin{array}{c}-0.089 * * \\
(0.048)\end{array}$ & $\begin{array}{c}0.059 \\
(0.192)\end{array}$ & 1 & \\
\hline TL/TA & $\begin{array}{c}-0.116^{* * *} \\
(0.01)\end{array}$ & $\begin{array}{c}-0.133 * * * \\
(0.003)\end{array}$ & $\begin{array}{c}-0.072 \\
(0.108)\end{array}$ & $\begin{array}{c}-0.088^{*} \\
(0.049)\end{array}$ & $\begin{array}{c}-0.167 * * * \\
(0.000)\end{array}$ & $\begin{array}{c}0.114 * * \\
(0.011)\end{array}$ & $\begin{array}{c}-0.101^{* *} \\
(0.024)\end{array}$ & $\begin{array}{l}-0.012 \\
(0.796)\end{array}$ & $\begin{array}{c}-0.465^{* * *} \\
(0.000)\end{array}$ & 1 \\
\hline
\end{tabular}

Note. $* * *, * *$, and $*$ mean the value is significant at the $0.01,0.05$, and 0.1 level of significance, respectively. 
Table 11. 2008 Correlation Matrix

\begin{tabular}{|c|c|c|c|c|c|c|c|c|c|c|}
\hline Variable & RAPROA & $\mathrm{HHI}_{\mathrm{Geo}}$ & $\mathrm{HHI}_{\text {Act }}$ & $\mathrm{HHI}_{\text {Loan }}$ & $\mathrm{SH}_{\mathrm{RE}}$ & TA & HCTMULT & Unemp Rate & $\mathrm{RBC}$ & TL/TA \\
\hline RAPROA & 1 & & & & & & & & & \\
\hline $\mathrm{HHI}_{\mathrm{Geo}}$ & $\begin{array}{l}-0.051 \\
(0.261)\end{array}$ & 1 & & & & & & & & \\
\hline $\mathrm{HHI}_{\mathrm{Act}}$ & $\begin{array}{c}0.003 \\
(0.951)\end{array}$ & $\begin{array}{l}0.085^{*} \\
(0.061)\end{array}$ & 1 & & & & & & & \\
\hline $\mathrm{HHI}_{\text {Loan }}$ & $\begin{array}{c}-0.079 * \\
(0.081)\end{array}$ & $\begin{array}{c}0.224 * * * \\
(0.000)\end{array}$ & $\begin{array}{c}0.142 * * * \\
(0.002)\end{array}$ & 1 & & & & & & \\
\hline $\mathrm{SH}_{\mathrm{RE}}$ & $\begin{array}{c}0.071 \\
(0.117)\end{array}$ & $\begin{array}{c}0.187 * * * \\
(0.000)\end{array}$ & $\begin{array}{c}-0.108^{* *} \\
(0.017)\end{array}$ & $\begin{array}{c}0.545^{* * *} \\
(0.000)\end{array}$ & 1 & & & & & \\
\hline TA & $\begin{array}{l}-0.064 \\
(0.160)\end{array}$ & $\begin{array}{c}-0.217 * * * \\
(0.000)\end{array}$ & $\begin{array}{c}-0.221^{* * *} \\
(0.000)\end{array}$ & $\begin{array}{c}0.043 \\
(0.341)\end{array}$ & $\begin{array}{c}0.036 \\
(0.434)\end{array}$ & 1 & & & & \\
\hline HCTMULT & $\begin{array}{l}0.086^{*} \\
(0.059)\end{array}$ & $\begin{array}{l}-0.061 \\
(0.181)\end{array}$ & $\begin{array}{c}0.011 \\
(0.804)\end{array}$ & $\begin{array}{c}-0.103 * * \\
(0.024)\end{array}$ & $\begin{array}{c}-0.094 * * \\
(0.038)\end{array}$ & $\begin{array}{l}-0.004 \\
(0.934)\end{array}$ & 1 & & & \\
\hline Unemp Rate & $\begin{array}{c}-0.118^{* * *} \\
(0.009)\end{array}$ & $\begin{array}{c}0.131 * * * \\
(0.004)\end{array}$ & $\begin{array}{c}0.017 \\
(0.715)\end{array}$ & $\begin{array}{c}0.196 * * * \\
(0.000)\end{array}$ & $\begin{array}{c}0.153 * * * \\
(0.001)\end{array}$ & $\begin{array}{c}0.031 \\
(0.494)\end{array}$ & $\begin{array}{l}-0.035 \\
(0.440)\end{array}$ & 1 & & \\
\hline $\mathrm{RBC}$ & $\begin{array}{c}0.170^{* * *} \\
(0.000)\end{array}$ & $\begin{array}{c}0.186^{* * *} \\
(0.000)\end{array}$ & $\begin{array}{c}0.205^{* * *} \\
(0.000)\end{array}$ & $\begin{array}{c}0.365^{* * *} \\
(0.000)\end{array}$ & $\begin{array}{c}0.297 * * * \\
(0.000)\end{array}$ & $\begin{array}{c}-0.148^{* * *} \\
(0.001)\end{array}$ & $\begin{array}{l}-0.072 \\
(0.115)\end{array}$ & $\begin{array}{c}0.032 \\
(0.478)\end{array}$ & 1 & \\
\hline TL/TA & $\begin{array}{c}-0.154 * * * \\
(0.001)\end{array}$ & $\begin{array}{c}-0.113 * * \\
(0.013)\end{array}$ & $\begin{array}{c}-0.097 * * \\
(0.034)\end{array}$ & $\begin{array}{c}-0.101 * * \\
(0.026)\end{array}$ & $\begin{array}{c}-0.228^{* * *} \\
(0.000)\end{array}$ & $\begin{array}{c}0.102 * * \\
(0.025)\end{array}$ & $\begin{array}{c}-0.078 * \\
(0.087) \\
\end{array}$ & $\begin{array}{r}-0.018 \\
(0.691) \\
\end{array}$ & $\begin{array}{c}-0.466^{* * *} \\
(0.000)\end{array}$ & 1 \\
\hline
\end{tabular}

Note. $* * *, * *$, and $*$ mean the value is significant at the $0.01,0.05$, and 0.1 level of significance, respectively. 
Table 12. 2009 Correlation Matrix

\begin{tabular}{|c|c|c|c|c|c|c|c|c|c|c|}
\hline Variable & RAPROA & $\mathrm{HHI}_{\mathrm{Geo}}$ & $\mathrm{HHI}_{\mathrm{Act}}$ & $\mathrm{HHI}_{\text {Loan }}$ & $\mathrm{SH}_{\mathrm{RE}}$ & TA & HCTMULT & Unemp Rate & $\mathrm{RBC}$ & TL/TA \\
\hline RAPROA & 1 & & & & & & & & & \\
\hline $\mathrm{HHI}_{\mathrm{Geo}}$ & $\begin{array}{l}-0.036 \\
(0.437)\end{array}$ & 1 & & & & & & & & \\
\hline $\mathrm{HHI}_{\mathrm{Act}}$ & $\begin{array}{l}-0.014 \\
(0.767)\end{array}$ & $\begin{array}{c}0.09 * \\
(0.055)\end{array}$ & 1 & & & & & & & \\
\hline $\mathrm{HHI}_{\text {Loan }}$ & $\begin{array}{l}-0.058 \\
(0.211)\end{array}$ & $\begin{array}{c}0.242^{* * *} \\
(0.000)\end{array}$ & $\begin{array}{c}0.14 * * * \\
(0.003)\end{array}$ & 1 & & & & & & \\
\hline $\mathrm{SH}_{\mathrm{RE}}$ & $\begin{array}{c}0.115^{* *} \\
(0.014)\end{array}$ & $\begin{array}{c}0.169 * * * \\
(0.000)\end{array}$ & $\begin{array}{c}-0.145 * * * \\
(0.002)\end{array}$ & $\begin{array}{c}0.489 * * * \\
(0.000)\end{array}$ & 1 & & & & & \\
\hline TA & $\begin{array}{c}-0.098 * * \\
(0.035)\end{array}$ & $\begin{array}{c}-0.236 * * * \\
(0.000)\end{array}$ & $\begin{array}{c}-0.225^{* * *} \\
(0.000)\end{array}$ & $\begin{array}{c}0.02 \\
(0.669)\end{array}$ & $\begin{array}{c}0.038 \\
(0.415)\end{array}$ & 1 & & & & \\
\hline HCTMULT & $\begin{array}{c}0.125 * * * \\
(0.007)\end{array}$ & $\begin{array}{l}-0.032 \\
(0.491)\end{array}$ & $\begin{array}{c}0.006 \\
(0.891)\end{array}$ & $\begin{array}{c}-0.091 * * \\
(0.05)\end{array}$ & $\begin{array}{l}-0.064 \\
(0.17)\end{array}$ & $\begin{array}{c}0.006 \\
(0.893)\end{array}$ & 1 & & & \\
\hline Unemp Rate & $\begin{array}{c}-0.15^{* * *} \\
(0.001)\end{array}$ & $\begin{array}{c}0.145^{* * *} \\
(0.002)\end{array}$ & $\begin{array}{l}-0.059 \\
(0.204)\end{array}$ & $\begin{array}{c}0.191 * * * \\
(0.000)\end{array}$ & $\begin{array}{c}0.143 * * * \\
(0.002)\end{array}$ & $\begin{array}{c}0.049 \\
(0.296)\end{array}$ & $\begin{array}{c}-0.054 \\
(0.248)\end{array}$ & 1 & & \\
\hline $\mathrm{RBC}$ & $\begin{array}{c}0.205^{* * *} \\
(0.000)\end{array}$ & $\begin{array}{c}0.124 * * * \\
(0.008)\end{array}$ & $\begin{array}{c}0.143 * * * \\
(0.002)\end{array}$ & $\begin{array}{c}0.354 * * * \\
(0.000)\end{array}$ & $\begin{array}{c}0.273 * * * \\
(0.000)\end{array}$ & $\begin{array}{c}-0.142 * * * \\
(0.002)\end{array}$ & $\begin{array}{c}-0.02 \\
(0.668)\end{array}$ & $\begin{array}{l}-0.008 \\
(0.865)\end{array}$ & 1 & \\
\hline TL/TA & $\begin{array}{c}-0.146^{* * *} \\
(0.002) \\
\end{array}$ & $\begin{array}{c}-0.071 \\
(0.127) \\
\end{array}$ & $\begin{array}{r}-0.068 \\
(0.145) \\
\end{array}$ & $\begin{array}{c}-0.125 * * * \\
(0.007) \\
\end{array}$ & $\begin{array}{c}-0.236^{* * *} \\
(0.000) \\
\end{array}$ & $\begin{array}{c}0.041 \\
(0.379) \\
\end{array}$ & $\begin{array}{c}-0.094 * * \\
(0.044)\end{array}$ & $\begin{array}{r}-0.041 \\
(0.382) \\
\end{array}$ & $\begin{array}{c}-0.468^{* * *} \\
(0.000)\end{array}$ & 1 \\
\hline
\end{tabular}

Note. $* * * * *$, and $*$ mean the value is significant at the $0.01,0.05$, and 0.1 level of significance, respectively. 
Table 13. 2010 Correlation Matrix

\begin{tabular}{|c|c|c|c|c|c|c|c|c|c|c|}
\hline Variable & RAPROA & $\mathrm{HHI}_{\mathrm{Geo}}$ & $\mathrm{HHI}_{\text {Act }}$ & $\mathrm{HHI}_{\text {Loan }}$ & $\mathrm{SH}_{\mathrm{RE}}$ & TA & HCTMULT & Unemp Rate & $\mathrm{RBC}$ & TL/TA \\
\hline RAPROA & 1 & & & & & & & & & \\
\hline $\mathrm{HHI}_{\mathrm{Geo}}$ & $\begin{array}{l}-0.034 \\
(0.476)\end{array}$ & 1 & & & & & & & & \\
\hline $\mathrm{HHI}_{\text {Act }}$ & $\begin{array}{l}-0.035 \\
(0.464)\end{array}$ & $\begin{array}{c}0.08^{*} \\
(0.093)\end{array}$ & 1 & & & & & & & \\
\hline $\mathrm{HHI}_{\text {Loan }}$ & $\begin{array}{l}-0.08 * \\
(0.094)\end{array}$ & $\begin{array}{c}0.239 * * * \\
(0.000)\end{array}$ & $\begin{array}{c}0.202^{* * *} \\
(0.000)\end{array}$ & 1 & & & & & & \\
\hline $\mathrm{SH}_{\mathrm{RE}}$ & $\begin{array}{c}0.065 \\
(0.174)\end{array}$ & $\begin{array}{c}0.162 * * * \\
(0.001)\end{array}$ & $\begin{array}{c}-0.118 * * \\
(0.013)\end{array}$ & $\begin{array}{c}0.445 * * * \\
(0.000)\end{array}$ & 1 & & & & & \\
\hline TA & $\begin{array}{c}-0.04 \\
(0.406\end{array}$ & $\begin{array}{c}-0.261 * * * \\
(0.000)\end{array}$ & $\begin{array}{c}-0.198 * * * \\
(0.000)\end{array}$ & $\begin{array}{c}0.02 \\
(0.673)\end{array}$ & $\begin{array}{l}0.084 * \\
(0.078)\end{array}$ & 1 & & & & \\
\hline HCTMULT & $\begin{array}{l}0.091 * \\
(0.057)\end{array}$ & $\begin{array}{l}-0.094 * \\
(0.051)\end{array}$ & $\begin{array}{l}-0.012 \\
(0.808)\end{array}$ & $\begin{array}{c}-0.097 * * \\
(0.043)\end{array}$ & $\begin{array}{c}-0.118 * * \\
(0.014)\end{array}$ & $\begin{array}{c}0.011 \\
(0.817)\end{array}$ & 1 & & & \\
\hline Unemp Rate & $\begin{array}{c}-0.158 * * * \\
(0.001)\end{array}$ & $\begin{array}{c}0.121 * * \\
(0.011)\end{array}$ & $\begin{array}{c}0.028 \\
(0.562)\end{array}$ & $\begin{array}{c}0.279 * * * \\
(0.000)\end{array}$ & $\begin{array}{c}0.133 * * * \\
(0.005)\end{array}$ & $\begin{array}{c}0.053 \\
(0.267)\end{array}$ & $\begin{array}{c}-0.076 \\
(0.111)\end{array}$ & 1 & & \\
\hline $\mathrm{RBC}$ & $\begin{array}{c}0.185^{* * *} \\
(0.000)\end{array}$ & $\begin{array}{c}0.146^{* * *} \\
(0.002)\end{array}$ & $\begin{array}{c}0.144 * * * \\
(0.003)\end{array}$ & $\begin{array}{c}0.345^{* * *} \\
(0.000)\end{array}$ & $\begin{array}{c}0.252 * * * \\
(0.000)\end{array}$ & $\begin{array}{l}-0.067 \\
(0.161)\end{array}$ & $\begin{array}{l}-0.014 \\
(0.773)\end{array}$ & $\begin{array}{c}0.067 \\
(0.164)\end{array}$ & 1 & \\
\hline TL/TA & $\begin{array}{c}-0.107 * * \\
(0.026)\end{array}$ & $\begin{array}{l}-0.053 \\
(0.272) \\
\end{array}$ & $\begin{array}{l}-0.049 \\
(0.310) \\
\end{array}$ & $\begin{array}{r}-0.074 \\
(0.124) \\
\end{array}$ & $\begin{array}{c}-0.169^{* * *} \\
(0.000)\end{array}$ & $\begin{array}{c}0.027 \\
(0.577) \\
\end{array}$ & $\begin{array}{l}-0.004 \\
(0.929) \\
\end{array}$ & $\begin{array}{l}-0.067 \\
(0.162) \\
\end{array}$ & $\begin{array}{c}-0.504 * * * \\
(0.000)\end{array}$ & 1 \\
\hline
\end{tabular}

Note. $* * *, * *$, and $*$ mean the value is significant at the $0.01,0.05$, and 0.1 level of significance, respectively. 
Table 14. 2011 Correlation Matrix

\begin{tabular}{|c|c|c|c|c|c|c|c|c|c|c|}
\hline Variable & RAPROA & $\mathrm{HHI}_{\mathrm{Geo}}$ & $\mathrm{HHI}_{\text {Act }}$ & $\mathrm{HHI}_{\text {Loan }}$ & $\mathrm{SH}_{\mathrm{RE}}$ & TA & HCTMULT & Unemp Rate & $\mathrm{RBC}$ & TL/TA \\
\hline RAPROA & 1 & & & & & & & & & \\
\hline $\mathrm{HHI}_{\mathrm{Geo}}$ & $\begin{array}{l}-0.033 \\
-0.497\end{array}$ & 1 & & & & & & & & \\
\hline $\mathrm{HHI}_{\text {Act }}$ & $\begin{array}{l}-0.049 \\
-0.319\end{array}$ & $\begin{array}{c}0.06 \\
(0.217)\end{array}$ & 1 & & & & & & & \\
\hline $\mathrm{HHI}_{\text {Loan }}$ & $\begin{array}{c}-0.119 * * \\
(0.014)\end{array}$ & $\begin{array}{c}0.236^{* * *} \\
(0.000)\end{array}$ & $\begin{array}{c}0.186^{* * * *} \\
(0.000)\end{array}$ & 1 & & & & & & \\
\hline $\mathrm{SH}_{\mathrm{RE}}$ & $\begin{array}{c}0.012 \\
(0.809)\end{array}$ & $\begin{array}{c}0.183 * * * \\
(0.000)\end{array}$ & $\begin{array}{l}-0.065 \\
(0.181)\end{array}$ & $\begin{array}{c}0.451^{* * *} \\
(0.000)\end{array}$ & 1 & & & & & \\
\hline TA & $\begin{array}{l}-0.007 \\
(0.892)\end{array}$ & $\begin{array}{c}-0.224 * * * \\
(0.000)\end{array}$ & $\begin{array}{c}-0.149 * * * \\
(0.002)\end{array}$ & $\begin{array}{c}0.024 \\
(0.627)\end{array}$ & $\begin{array}{c}0.08 * \\
(0.1)\end{array}$ & 1 & & & & \\
\hline HCTMULT & $\begin{array}{c}0.13 * * * \\
(0.008)\end{array}$ & $\begin{array}{l}-0.077 \\
(0.113)\end{array}$ & $\begin{array}{c}0.029 \\
(0.554)\end{array}$ & $\begin{array}{c}-0.105 * * \\
(0.031)\end{array}$ & $\begin{array}{c}-0.118 * * \\
(0.015)\end{array}$ & $\begin{array}{c}0.031 \\
(0.523)\end{array}$ & 1 & & & \\
\hline $\begin{array}{l}\text { Unemp } \\
\text { Rate }\end{array}$ & $\begin{array}{c}-0.171 * * * \\
(0.000)\end{array}$ & $\begin{array}{l}0.081 * \\
(0.098)\end{array}$ & $\begin{array}{c}0.088 * \\
(0.07)\end{array}$ & $\begin{array}{c}0.255^{* * *} \\
(0.000)\end{array}$ & $\begin{array}{c}0.132 * * * \\
(0.007)\end{array}$ & $\begin{array}{c}0.041 \\
(0.399)\end{array}$ & $\begin{array}{l}-0.089 * \\
(0.066)\end{array}$ & 1 & & \\
\hline $\mathrm{RBC}$ & $\begin{array}{c}0.154 * * * \\
(0.001)\end{array}$ & $\begin{array}{c}0.13^{* * *} \\
(0.007)\end{array}$ & $\begin{array}{c}0.043 \\
(0.374)\end{array}$ & $\begin{array}{c}0.311^{* * *} \\
(0.000)\end{array}$ & $\begin{array}{c}0.239 * * * \\
(0.000)\end{array}$ & $\begin{array}{l}-0.055 \\
(0.26)\end{array}$ & $\begin{array}{l}-0.027 \\
(0.586)\end{array}$ & $\begin{array}{l}0.092^{*} \\
(0.058)\end{array}$ & 1 & \\
\hline TL/TA & $\begin{array}{r}-0.082 \\
(0.09) \\
\end{array}$ & $\begin{array}{c}0.002 \\
(0.966) \\
\end{array}$ & $\begin{array}{c}.02 \\
(0.68) \\
\end{array}$ & $\begin{array}{r}-0.039 \\
(0.429) \\
\end{array}$ & $\begin{array}{c}-0.174 * * * \\
(0.000)\end{array}$ & $\begin{array}{c}0.009 \\
(0.851) \\
\end{array}$ & $\begin{array}{l}0.005 \\
0.918 \\
\end{array}$ & $\begin{array}{r}-0.062 \\
(0.203) \\
\end{array}$ & $\begin{array}{c}-0.499 * * * \\
(0.000)\end{array}$ & 1 \\
\hline
\end{tabular}

Note. $* * * * *$, and $*$ mean the value is significant at the $0.01,0.05$, and 0.1 level of significance, respectively. 
Table 15. Regression Results

\begin{tabular}{|c|c|c|c|c|c|}
\hline \multicolumn{6}{|c|}{ Dependent Variable: Risk-Adjusted ROA (RAPROA) } \\
\hline & 2007 & 2008 & 2009 & 2010 & 2011 \\
\hline \multirow[t]{2}{*}{ Intercept } & $7.07 * * *$ & $6.737 * * *$ & $6.028 * *$ & $5.474 * *$ & $5.110^{* *}$ \\
\hline & (3.116) & $(2.924)$ & $(2.461)$ & $(2.149)$ & $(2.118)$ \\
\hline \multirow{2}{*}{$\mathrm{HHI}_{\mathrm{Geo}}$} & -1.330 & -1.638 & -1.165 & -0.842 & -0.375 \\
\hline & $(1.195)$ & $(-1.442)$ & $(-0.995)$ & $(-0.674)$ & $(-0.296)$ \\
\hline \multirow[t]{2}{*}{$\mathrm{HHI}_{\text {Act }}$} & -1.793 & -0.052 & -0.709 & -0.935 & -0.496 \\
\hline & $(-1.097)$ & $(-0.031)$ & $(-0.410)$ & $(-0.514)$ & $(-0.26)$ \\
\hline \multirow[t]{2}{*}{$\mathrm{HHI}_{\text {Loan }}$} & $-7.367 * * *$ & $-6.959 * * *$ & $-6.429 * * *$ & $-5.994 * *$ & $-6.624 * * *$ \\
\hline & $(3.727)$ & $(-3.253)$ & $(3.101)$ & $(-2.514)$ & $(-2.811)$ \\
\hline \multirow[t]{2}{*}{$\mathrm{SH}_{\mathrm{RE}}$} & 2.665 & $4.323 * *$ & $5.468 * * *$ & $3.762 * *$ & 2.456 \\
\hline & $(1.637)$ & $(2.541)$ & $(3.101)$ & $(1.968)$ & $(1.314)$ \\
\hline \multirow[t]{2}{*}{ Total Assets (TA) } & -0.000001301 & -0.0000008964 & -0.000001893 & -0.0000009329 & 0.00000001208 \\
\hline & $(-1.197)$ & $(-0.844)$ & $(-1.716)$ & $(-0.78)$ & $(0.01)$ \\
\hline Multi-Bank Holding Co (MBHC) & $(1.258)$ & $(1.841)$ & $(2.545)$ & $(1.701)$ & $(2.376)$ \\
\hline Unemployment Rate & -0.002 & $-0.416^{* *}$ & $-0.342 * * *$ & $-0.367 * * *$ & $-0.408 * * *$ \\
\hline \multirow[t]{2}{*}{ Total Risk-Based Capital (RBC) } & $\begin{array}{c}(-0.010) \\
12.841 * * *\end{array}$ & $\begin{array}{c}(-2.153) \\
16.565^{* * *}\end{array}$ & $\begin{array}{c}(-2.747) \\
17.871 * * *\end{array}$ & $\begin{array}{c}(-2.747) \\
19.238^{* * *}\end{array}$ & $\begin{array}{c}(-2.967) \\
17.08 * * *\end{array}$ \\
\hline & $(2.764)$ & $(3.448)$ & $(3.742)$ & $(3.927)$ & $(3.781)$ \\
\hline \multirow[t]{2}{*}{ Total Loans/Total Assets (TL/TA) } & -1.756 & -1.872 & -1.06 & 0.173 & 0.895 \\
\hline & $(-0.957)$ & $(-1.019)$ & $(-0.548)$ & $(0.08)$ & $(0.421)$ \\
\hline No. Observations & 490 & 484 & 461 & 437 & 423 \\
\hline R-Square & 0.063 & 0.089 & 0.118 & 0.092 & 0.093 \\
\hline Adjusted R-Square & 0.045 & 0.072 & 0.100 & 0.073 & 0.073 \\
\hline \multirow[t]{2}{*}{ F-test } & $3.571 * * *$ & $5.165^{* * *}$ & $6.682 * * *$ & $4.81 * * *$ & $4.682 * * *$ \\
\hline & $(0.000)$ & $(0.000)$ & $(0.000)$ & $(0.000)$ & $(0.000)$ \\
\hline
\end{tabular}

Note. $* * * * *$, and $*$ mean the value is significant at the $0.01,0.05$, and 0.1 level of significance, respectively. 
Table 16. Geographic Diversification Means by Asset Size \& ANOVA Test Results

\begin{tabular}{|c|c|c|c|c|c|c|c|}
\hline & $\begin{array}{l}\text { Total Assets } \\
\$ 100 \mathrm{M}-\$ 250 \mathrm{M}\end{array}$ & $\begin{array}{l}\text { Total Assets } \\
\$ 250 \mathrm{M}-\$ 500 \mathrm{M}\end{array}$ & $\begin{array}{c}\text { Total Assets } \\
\$ 500 \mathrm{M}-\$ 750 \mathrm{M} \\
\end{array}$ & $\begin{array}{l}\text { Total Assets } \\
\$ 750 \mathrm{M}-\$ 1 \mathrm{~B}\end{array}$ & Total & F-Statistic & p-value \\
\hline 2007 & 0.8728 & 0.8341 & 0.8243 & 0.6853 & 0.8445 & 8.480 & 0.000 \\
\hline 2008 & 0.8715 & 0.8312 & 0.8196 & 0.7074 & 0.8412 & 6.947 & 0.000 \\
\hline $\mathrm{n}$ & 234 & 159 & 62 & 31 & 486 & & \\
\hline 2009 & 0.8759 & 0.8169 & 0.8498 & 0.6669 & 0.8364 & 11.729 & 0.000 \\
\hline $\mathrm{n}$ & 203 & 166 & 60 & 33 & 462 & & \\
\hline 2010 & 0.8767 & 0.8036 & 0.8131 & 0.6826 & 0.8288 & 10.255 & 0.000 \\
\hline $\mathrm{n}$ & 194 & 162 & 53 & 30 & 439 & & \\
\hline 2011 & 0.8629 & 0.8217 & 0.7967 & 0.7280 & 0.8303 & 4.977 & 0.002 \\
\hline $\mathrm{n}$ & 189 & 154 & 51 & 30 & 424 & & \\
\hline
\end{tabular}

Table 17. Activity Diversification Means by Asset Size \& ANOVA Test Results

\begin{tabular}{|c|c|c|c|c|c|c|c|}
\hline & $\begin{array}{c}\text { Total Assets } \\
\$ 100 \mathrm{M}-\$ 250 \mathrm{M} \\
\end{array}$ & $\begin{array}{c}\text { Total Assets } \\
\$ 250 \mathrm{M}-\$ 500 \mathrm{M} \\
\end{array}$ & $\begin{array}{c}\text { Total Assets } \\
\$ 500 \mathrm{M}-\$ 750 \mathrm{M} \\
\end{array}$ & $\begin{array}{l}\text { Total Assets } \\
\$ 750 \mathrm{M}-\$ 1 \mathrm{~B}\end{array}$ & Total & F-Statistic & p-value \\
\hline 2007 & 0.4952 & 0.4471 & 0.3929 & 0.3853 & 0.4624 & 13.510 & 0.000 \\
\hline 2008 & 0.4808 & 0.4396 & 0.3842 & 0.4075 & 0.4501 & 9.920 & 0.000 \\
\hline $\mathrm{n}$ & 234 & 159 & 62 & 31 & 486 & & \\
\hline 2009 & 0.4681 & 0.4255 & 0.3832 & 0.3723 & 0.4349 & 9.463 & 0.000 \\
\hline 2010 & 0.4466 & 0.4169 & 0.3795 & 0.3628 & 0.4218 & 5.481 & 0.000 \\
\hline $\mathrm{n}$ & 194 & 162 & 53 & 30 & 439 & & \\
\hline 2011 & 0.4304 & 0.4042 & 0.3807 & 0.3675 & 0.4104 & 3.451 & 0.017 \\
\hline $\mathrm{n}$ & 189 & 154 & 51 & 30 & 424 & & \\
\hline
\end{tabular}


Table 18. Non-Traditional Noninterest Income/Total Noninterest Income by Size Groups

\begin{tabular}{lcccc}
\hline Asset Size & 2007 & 2008 & 2009 & 2010 \\
\hline \$100 Million - \$250 Million & 0.0678 & -0.0882 & 0.0660 & 0.0697 \\
\$250 Million - \$500 Million & 0.0851 & 0.0006 & 0.0751 & 0.0917 \\
\$500 Million - \$750 Million & 0.1072 & 0.0003 & 0.0893 & 0.0906 \\
\$750 Million - \$1 Billion & 0.0855 & 0.0002 & 0.0968 & 0.1075 \\
\hline
\end{tabular}

Table 19. Asset Diversification Means by Asset Size \& ANOVA Test Results

\begin{tabular}{|c|c|c|c|c|c|c|c|}
\hline & $\begin{array}{c}\text { Total Assets } \\
\$ 100 \mathrm{M}-\$ 250 \mathrm{M}\end{array}$ & $\begin{array}{c}\text { Total Assets } \\
\text { \$250M-\$500M }\end{array}$ & $\begin{array}{c}\text { Total Assets } \\
\$ 500 \mathrm{M}-\$ 750 \mathrm{M}\end{array}$ & $\begin{array}{l}\text { Total Assets } \\
\$ 750 \mathrm{M}-\$ 1 \mathrm{~B}\end{array}$ & Total & F-Statistic & $\mathrm{p}$-value \\
\hline 2007 & 0.2995 & 0.2978 & 0.3246 & 0.3149 & 0.3026 & 0.680 & 0.565 \\
\hline $\mathrm{n}$ & 258 & 157 & 55 & 2 & 500 & & \\
\hline 2008 & 0.2962 & 0.2918 & 0.3265 & 0.3062 & 0.2993 & 1.147 & 0.330 \\
\hline $\mathrm{n}$ & 233 & 159 & 62 & 31 & 486 & & \\
\hline 2009 & 0.3042 & 0.2935 & 0.3324 & 0.2855 & 0.3027 & 1.574 & 0.195 \\
\hline $\mathrm{n}$ & 202 & 166 & 60 & 33 & 462 & & \\
\hline 2010 & 0.3100 & 0.2981 & 0.3275 & 0.3045 & 0.3073 & 0.779 & 0.506 \\
\hline $\mathrm{n}$ & 193 & 162 & 53 & 30 & 439 & & \\
\hline 2011 & 0.3110 & 0.3088 & 0.3135 & 0.3310 & 0.3120 & 0.267 & 0.849 \\
\hline $\mathrm{n}$ & 188 & 154 & 51 & 30 & 424 & & \\
\hline
\end{tabular}


Table 20. Impact of Diversification Changes on $\mathrm{RAP}_{\mathrm{ROA}}$

\begin{tabular}{|c|c|c|c|c|c|c|c|}
\hline Variable & 5-yr Avg & 5-yr Avg Min & 5-yr Avg Max & $\begin{array}{c}\text { 5-yr Avg } \\
\text { Coefficient } \\
\end{array}$ & $\begin{array}{l}\text { Max to Min Avg } \\
\text { Diversification }\end{array}$ & $\begin{array}{l}\text { Impact on } \\
\text { RAPROA }\end{array}$ & $\begin{array}{c}\text { Percent of Avg } \\
\text { RAPROA }\end{array}$ \\
\hline RAPROA & 3.463 & -6.192 & 33.251 & N/A & N/A & N/A & N/A \\
\hline HHIGeo & 0.836 & 0.286 & 1.000 & -1.070 & -0.714 & 0.764 & $22 \%$ \\
\hline HHIAct & 0.435 & 0.205 & 0.958 & -0.797 & -0.752 & 0.600 & $17 \%$ \\
\hline HHILoan & 0.305 & 0.145 & 0.972 & -6.675 & -0.827 & 5.520 & $159 \%$ \\
\hline
\end{tabular}


Appendix: Regression Results with $\log \mathrm{RAP}_{\mathrm{ROA}}$

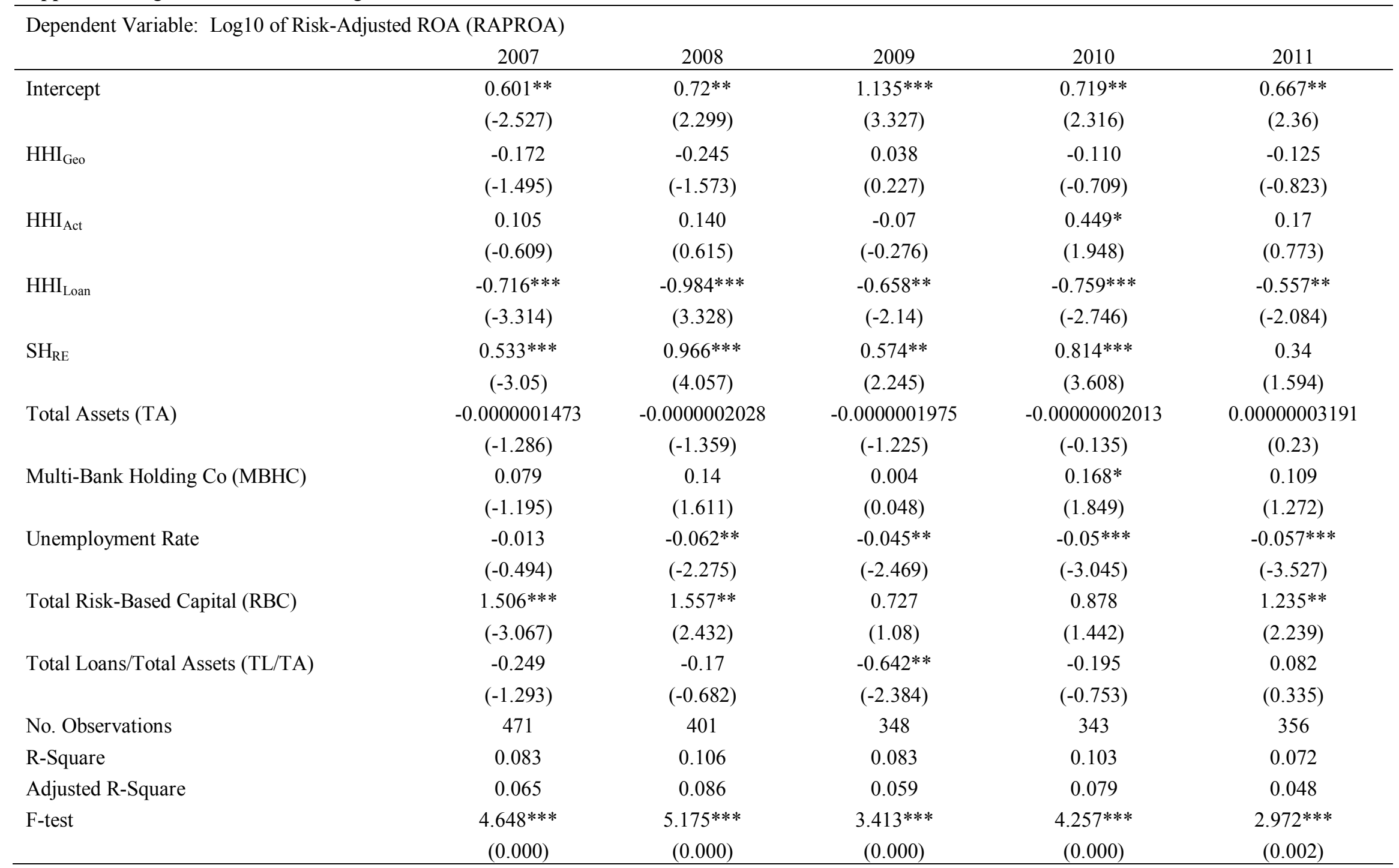

Note. ${ }^{* * *}, * *$, and $*$ mean the value is significant at the $0.01,0.05$, and 0.1 level of significance, respectively. 